\title{
Interventions promoting active transport to school in children: A systematic review and meta-analysis
}

Jones, R. A., Blackburn, N., Woods, C., Byrne, M., van Nassau, F., \& Tully, M. (2019). Interventions promoting active transport to school in children: A systematic review and meta-analysis. Preventive Medicine, 123, 232241. https://doi.org/10.1016/j.ypmed.2019.03.030

Link to publication record in Ulster University Research Portal

\section{Published in:}

Preventive Medicine

Publication Status:

Published (in print/issue): 01/06/2019

DOI:

10.1016/j.ypmed.2019.03.030

\section{Document Version}

Author Accepted version

\section{General rights}

Copyright for the publications made accessible via Ulster University's Research Portal is retained by the author(s) and / or other copyright owners and it is a condition of accessing these publications that users recognise and abide by the legal requirements associated with these rights.

\section{Take down policy}

The Research Portal is Ulster University's institutional repository that provides access to Ulster's research outputs. Every effort has been made to ensure that content in the Research Portal does not infringe any person's rights, or applicable UK laws. If you discover content in the Research Portal that you believe breaches copyright or violates any law, please contact pure-support@ulster.ac.uk. 
Interventions promoting active transport to school in children: a systematic review and meta-analysis.

Rebecca A Jones a , Nicole E Blackburn ${ }^{\text {a }}$, Catherine Woods ${ }^{b}$, Molly Byrne ${ }^{\mathrm{c}}$, Femke van Nassau ${ }^{\mathrm{d}}$, Mark A Tully a,e,f

${ }^{a}$ Centre for Public Health, Queen's University Belfast, Institute of Clinical Sciences, Block B, Royal Victoria Hospital, Belfast, BT12 6BA, Northern Ireland.

${ }^{\mathrm{b}}$ University of Limerick, Limerick, V94 T9PX, Ireland

${ }^{\mathrm{c}}$ Health Behaviour Change Research Group, National University of Ireland Galway, University Road, Galway, Ireland.

d Amsterdam UMC, Vrije Universiteit Amsterdam, Department of Public and Occupational Health, Amsterdam Public Health research institute, Van der Boechorststraat 7, NL-1081 BT Amsterdam, The Netherlands

${ }^{\mathrm{e}}$ UK Clinical Research Collaboration Centre of Excellence for Public Health, Centre for Public Health, School of Medicine, Dentistry and Biomedical Sciences, Queen’s University Belfast, United Kingdom

f Institute of Mental Health Sciences, School of Health Sciences, Ulster University, Shore Road, Newtownabbey, Co Antrim, BT37 0QB

\section{Author's names and affiliations:}

Rebecca A Jones - rj397@cam.ac.uk - Present address: MRC Epidemiology Unit, University of Cambridge, Cambridge, CB2 0QQ, United Kingdom.

Nicole EBlackburn - n.blackburn@qub.ac.uk; Catherine Woods - Catherine.Woods@ul.ie; Molly Byrne molly.byrne@nuigalway.ie; Femkevan Nassau- f.vannassau@vumc.nl;

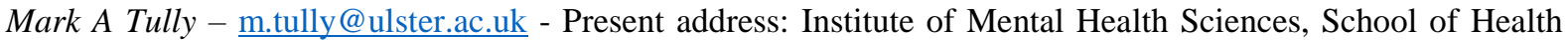
Sciences, Ulster University, Shore Road, Newtownabbey, Co Antrim, BT37 0QB, United Kingdom.

Corresponding author: The corresponding author has since moved to University of Cambridge. Present address: MRC Epidemiology Unit, University of Cambridge, Cambridge, CB2 0QQ, United Kingdom. Email address: ri397@cam.ac.uk (R A Jones)

Conflicts of interest: none.

Word count: Abstract -249 words / Main text -4486 words

Funding: This research did not receive any specific grant from funding agencies in the public, commercial, or not-for-profit sectors. 


\begin{abstract}
The systematic review investigated the effectiveness of active travel (AT) interventions on physical activity and fitness in primary school children. The review assessed intervention effectiveness, design, complexity, and study quality.

Searches were conducted in five databases on 30/08/2018. Studies with an AT intervention compared to an inactive control, in 4 to 11 year olds, measuring AT or fitness outcomes were included. Two-stage screening identified relevant studies. Relevant data were extracted using Cochrane Extraction Form, Quality Assessment Tool for Quantitative Studies, Active Living by Design model, and intervention Complexity Assessment Tool for Systematic Reviews. Meta-analysis and Cohen’s D effect size assessed effectiveness.

Seventeen eligible studies were included. Effectiveness assessment found a statistically significant standardised mean difference (SMD) in AT outcomes in favour of the intervention (continuous AT - SMD 0.78 (CI 0.111.46); frequency AT - SMD 1.87 (CI 0.88-2.86)). Cohen's D calculation concurred with this finding. Fifteen studies had SMD favouring the intervention - two studies had SMD favouring the control. Sixteen studies received a weak quality rating - one study rated moderate.

Active travel shows promise in increasing physical activity in primary school children. The review found walking school buses and educational strategies most effective for increasing relevant outcomes, although overall study quality was weak. Effect size did not associate with the complexity of an intervention, therefore supporting efforts to promote active travel through interventions may be easier to scale. Further intervention studies of greater methodological quality are necessary to confirm these findings due to the limited evidence available.
\end{abstract}

Key words: Active travel; School children; Public health; Intervention programs; Physical activity; Transport. 


\section{Introduction}

Regular participation in physical activity (PA) reduces overall cardio-metabolic risk, with inactive children at a significantly greater risk of hypertension, obesity and cancer than their physically active peers. ${ }^{1-2}$ Associated psychological benefits include improved cognition, self-esteem and emotional well-being, with reduced risk of depression and anxiety. ${ }^{3-8}$ Furthermore, there are improvements to academic behaviour and performance from PA interventions in schools. ${ }^{9}$ In 2017, National Health Service reported an increase in the proportion of children meeting the PA guidelines between 2012 to 2015 (boys: $21 \%$ to 23\%; girls: $16 \%$ to $20 \%$ ). ${ }^{10}$ Although this rise is promising, the proportion of children meeting the guidelines is still low. Overall, only $22 \%$ of children aged 5 to 15 years met the national guidelines for PA. ${ }^{10-11}$ Similarly low physical activity participation rates are evident globally. ${ }^{12}$

Active travel is widely recommended for promoting PA, with research suggesting it is one of the simplest and most acceptable forms of PA that is easily incorporated into everyday lives. ${ }^{13-17}$ In 2016 , researchers stated that comprehensive national and international initiatives to re-normalise active transport to school are necessary to address the decline in children's PA levels. ${ }^{18}$ International research shows a decrease in the number of children using an active form of transport to school. ${ }^{19-21}$ The global decline in the use of active travel modes to school by children is of concern. Active travel not only benefits child health through PA, it reduces injury rates, minimises environment damage and improves body composition. ${ }^{21}$ Additional benefits include reduced traffic congestion, economic savings and minimised noise pollution. ${ }^{21}$ Active travel is a practical and sustainable way to increase PA, with the benefits beyond health gains. ${ }^{22}$ The Institute of Medicine reports that active transport provides an excellent opportunity to be active, with family and community involvement increasing sustainability. ${ }^{19}$

In 2010, a systematic review investigated the effectiveness of school-based active transportation interventions in increasing active commuting to school in 6-18 year olds. ${ }^{23}$ The search identified 14 studies from various countries including United States, Australia and United Kingdom. Although the eligibility criteria included ages up to 18 years, all included studies (except one) focused on children between 5 to 12 years old. The review concluded that there was a small positive effect on active transport to school, noting heterogeneity in 'size, scope and focus' of the included interventions. ${ }^{23}$ In 2018, Villa-Gonzalez and colleagues produced an update of this review, with 23 included studies. ${ }^{24}$ Most included studies reported a small effect size on active travel to school, with 21 studies rated poor quality. ${ }^{24}$

Active travel research has grown substantially in past years, however there lacks a recent, comprehensive review of the effectiveness of interventions to promote active travel. Furthermore, previous research and review findings present conflicting conclusions. An updated systematic review to evaluate the effect of active travel interventions in primary school aged children is necessary to fill a gap in knowledge, and provide a comprehensive summary of effectiveness. Furthermore, the lack of intervention description in previous research highlights the need for descriptive analysis, including complexity analysis, in the current review. Therefore the aim of this study was to systematically review the effectiveness of active travel interventions in primary school children. 


\section{Method}

This systematic review adhered to the PRISMA reporting guidelines for systematic reviews. ${ }^{25}$

\section{Search procedure}

A literature search was conducted in MEDLINE, Web of Science, PsychINFO, EMBASE and TRIS for published studies up to $30^{\text {th }}$ August 2018, without date restrictions. No restriction on language was placed at this stage to allow authors to attempt to identify English language translations of articles. The search was inclusive of all publication types, with search terms identified from previous review studies and relevant MeSH headings. ${ }^{23-24,26-27}$ Search strategies and terms were adapted as necessary for each database (Supplement A).

\section{Eligibility criteria}

Participants: Only studies in which all participants, or the majority (>50\%) of participants, were $4-11$ years old attending primary school or equivalent were included.

Intervention: Eligible studies involved school-based active travel interventions among primary school children. Active travel interventions were defined as targeting the journey to and from school using a physically active form of transport (e.g. walking, cycling). Studies including additional PA co-interventions (e.g. sport participation or active school lessons) were excluded to ensure the findings were directly related to active transport only. Non-PA co-interventions (e.g. nutrition, mental health) were deemed acceptable.

Comparator: Only studies with a control group, where no PA intervention was provided, were eligible for inclusion.

Outcome: Studies with at least one outcome related to active transportation or physical fitness, measured either objectively or subjectively at baseline and on at least one occasion post intervention, were eligible for inclusion. Outcomes included, but were not exclusive to, daily steps, frequency of active travel and PA levels.

Study design: Eligible studies were controlled quantitative designs. Included study designs were randomised control trials (RCT), cluster RCT and controlled quantitative quasi-experimental studies. Within the context of this review, quasi-experimental studies are controlled before and after evaluations of planned but nonrandomised interventions, often used when randomisation is not possible because the delivery of the intervention is outside of the control of researchers. ${ }^{28-29}$ Non-controlled, cohort, and case studies were excluded, as were studies written in a non-English language. Authors manually searched for published English language translations of non-English language papers.

\section{Selection and review process}

Potentially relevant studies were compiled and duplicates removed using a reference manager (RefWorks, ProQuest, Michigan, USA). ${ }^{34}$ Titles and abstracts were screened for inclusion independently by three investigators (RJ, MT, NB). Relevant reviews were included at this stage for reference screening. The full-text 
of potentially relevant studies were subsequently assessed for inclusion independently by investigators (RJ, MT, NB). Any discrepancies were discussed by investigators for an agreed decision. A third investigator (MT) assisted to resolve any discrepancies where required.

\section{Data extraction}

\section{Characteristics of Included Studies}

Data extraction was completed independently by two investigators (RJ and MT) using a modified Cochrane Public Health Group Data Extraction Form. ${ }^{35}$ Extraction forms were piloted with two studies to ensure it was fit for purpose.

\section{Quality Assessment of Individual Studies}

The methodological quality of included studies was assessed using the Quality Assessment Tool for Quantitative Studies (QATQS). ${ }^{36}$ This tool has been recommended by the Cochrane Collaboration for use in systematic reviews. ${ }^{35}$ An overall rating of methodological quality (strong/moderate/weak) was assessed by extracting information across six domains: selection bias; study design; confounders; blinding; data collection methods; withdrawals and dropouts. All six components contributed to the calculation of the study's global rating. A study's global rating is dependent on the number of component rated weak study (weak -2 or more; moderate - 1; strong - none). Intervention integrity and analysis assessment were also included in the tool but did not contribute to the global rating. The component 'blinding' was modified to exclude participant blinding from influencing the study quality due to the inability to blind participants in active travel interventions. The characteristics of the QATQS have been evaluated and shown validity, test-retest reliability and inter-rater reliability ${ }^{35}$. Information from quality assessment was used for descriptive analysis of study quality and risk of bias. Two authors (RJ and MT) independently appraised study quality of all included studies, with discrepancies resolved through discussion.

\section{Assessment of Intervention Strategy Usage}

The design of each intervention was described using the Active Living by Design Community Action Model. ${ }^{37}$ This model has been successfully applied in active transport to school studies previously. ${ }^{38-39}$ The included studies were assessed for explicit referral of the model strategies (5P's): preparation, promotions, programs, policies and physical projects.

\section{Assessment of Intervention Complexity}

The complexity of the studies included was assessed using the intervention Cochrane Collaboration's intervention Complexity Assessment Tool for Systematic Reviews (iCAT_SR). ${ }^{40}$ The tool assessed various 
dimensions of the studies and categorised the level of complexity as 'complex', 'moderately complex' or 'simple'. The dimensions assessed included: the number of active components, level of skill required for intervention delivery and the level of component interaction. The global score for each included study was calculated by the sum of the individual component rating scores (simple $=1$, moderately complex $=2$, complex=3). The tool was piloted on two studies by both investigators to ensure consistency in the way it was applied. Two authors (RJ and MT) independently appraised intervention complexity of all included studies, with discrepancies resolved through discussion.

The relationship between complexity and effectiveness was assessed through scatter plot and correlation using IBM SPSS Statistics 23 software. In a scatter plot, each study's global score for complexity was plotted against effect size (Cohen's D). If a study had multiple outcomes, the mean of the calculated effect sizes was used. From the scatter plot, identification of a possible correlation was determined. A Spearman's rank-order correlation test was used as the data did not meet parametric assumptions (Shapiro-Wilk: $p<0.05$ ). The purpose of conducting a correlation test was to investigate if there was a relationship between complexity and effectiveness in terms of strength of association ( $r$-value) and significance ( $p$-value).

\section{Statistical Analyses of Intervention Effectiveness}

Continuous data were synthesised using random effects meta-analysis (RevMan v5.3, Cochrane Collaboration). Differences in outcomes between the intervention and controls at follow-up were compared. As a variety of outcomes measures were used, standardised mean difference was calculated. Separate meta-analyses were conducted for continuous measures of active travel (e.g. minutes per week), frequency of active travel (e.g. active travel journeys per week) and continuous measures of physical fitness (e.g. aerobic capacity). Within these outcome types, studies were further sub-divided by outcome type for sub-group and overall effect analysis. Heterogeneity using the $\mathrm{I}^{2}$ statistic was calculated for all analyses. Publication bias of the studies included in the meta-analysis was assessed using a funnel plot.

Study data, regardless of data type, were further synthesised by the calculation of Cohen's d effect size. The effect size between intervention and control groups and baseline and follow-up was calculated using standardised mean/proportion difference. Cohen's D classified effect size as trivial $(d<0.2)$, small $(d=0.2-0.5)$, moderate $(d=0.5-0.8)$, large $(d=0.8-1)$, and very large $(d<1) .^{23,41}$ 


\section{Results}

Study selection

The electronic search of the selected databases produced a total of 3,431 potentially relevant studies (Medline $(n=266)$, EMBASE $(n=320)$, PsycINFO $(n=358)$, Web of Science $(n=2,403)$, TRIS $(n=84))$. Duplication checks resulted in the removal of 248 studies.

A total of 3,183 potentially relevant studies remained for title, abstract and key word screening. 3,099 studies were excluded, leaving 84 studies for full-text screening. The screening of reference lists of potentially relevant studies and reviews identified 19 additional potentially relevant studies. After full-text screening and eligibility assessments of 103 studies, 17 studies met the inclusion criteria and were included in the review. ${ }^{30,32,42-56}$ Any disagreements during screening were discussed by the investigators for a jointly agreed decision. Figure 1 represents the selection and review process in flow diagram format in line with PRISMA guidelines. ${ }^{57}$ 


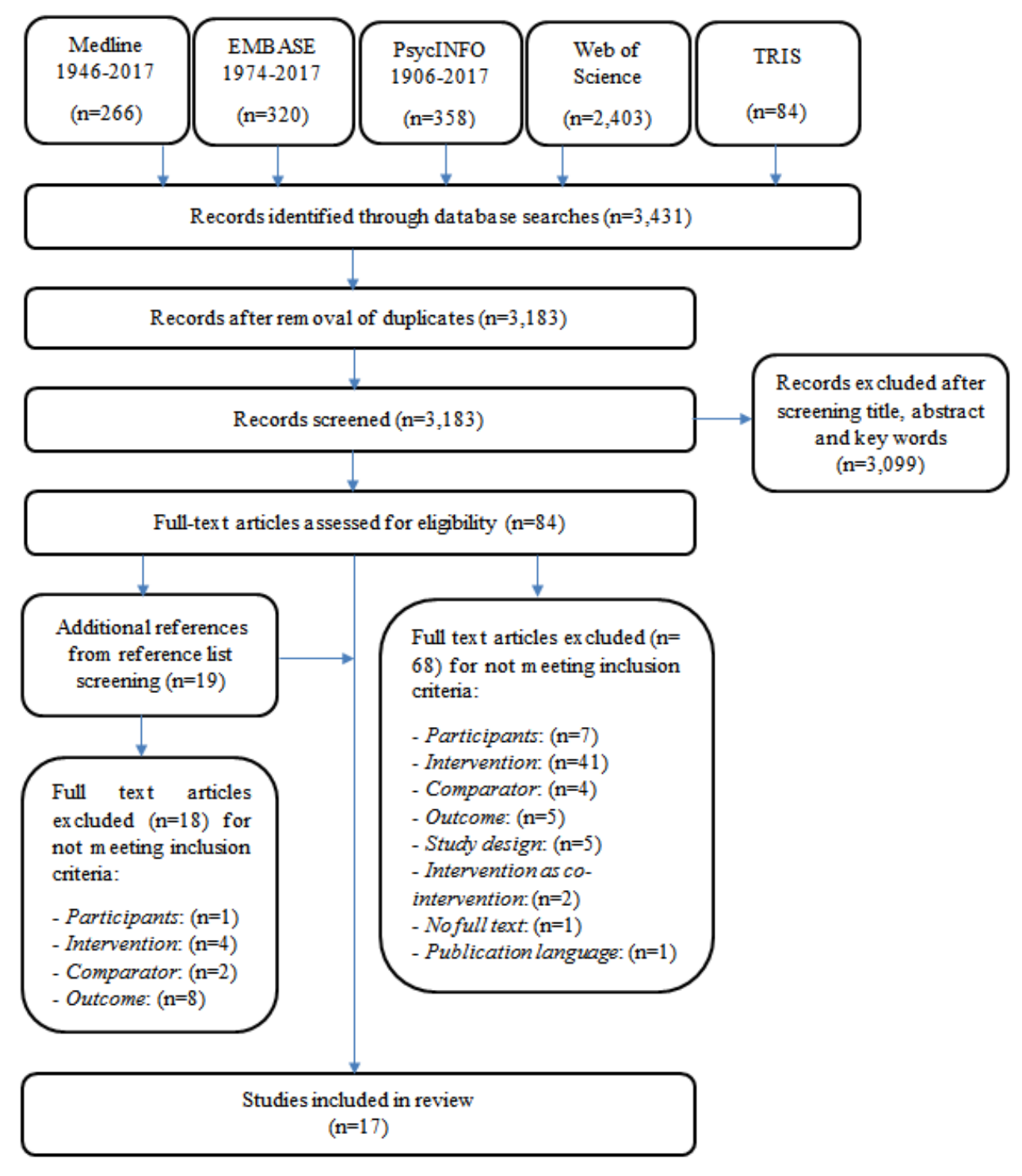

Figure 1. Flow diagram representing the selection and review process.

\section{Study characteristics}

The characteristics of the included review studies are included in Supplement B. Whilst the participant groups were relatively similar across studies, the interventions were significantly heterogeneous in terms of study duration, intervention type, outcome measures and duration of follow-up.

Eight quasi-experimental studies, four randomised control trials, three controlled trials, one cluster randomised control trial and one controlled cohort analytic study have been included in this review. Seven studies were conducted in United States and four studies were conducted in the United Kingdom. The remaining studies were conducted in Australia, Norway, Belgium, Demark and Spain.

Intervention types across studies were diverse. Four interventions were walking school buses, and seven focused on education and encouragement of active travel. One study involved both education and encouragement 
alongside a one-day active travel event. Two studies provided cycling training, and one study utilised modern technology through street sensor activation. The remaining two interventions were in the form of infrastructure changes, with one of these studies also incorporating funding allocation as part of the intervention. Intervention duration also varied greatly across the included studies ranging from a 1-day event to 2 year interventions. The majority of interventions lasted between 4-12 weeks.

The majority of studies included children at the upper end of the age range (8-11 years old), with only one study including children as young as 5 years old. The outcome measures varied significantly, increasing the difficultly of study comparisons. All studies, excluding one, provided an outcome measure of active travel with only one study providing only a measure of fitness (maximal oxygen consumption $\left(\mathrm{VO}^{2}{ }_{\max }\right)$ ).

Many studies used self-report methods completed by the student or parent, increasing the likelihood of response recall or social desirability bias. ${ }^{58}$ Despite many studies using these methods, some studies used valid and reliable objective forms of measurement (e.g. Actigraph ${ }^{47}$, cycle ergometer ${ }^{51}$ ), evidencing the feasibility of using more sensitive and accurate methods. ${ }^{49,52}$

\section{Quality of Included Studies}

The methodological quality of included studied was completed using the EPHPP tool. All studies, excluding one, were concluded to be of weak overall quality (global rating). Despite the inclusion of only controlled experimental designs, nine studies scored weak quality for study design. Quasi-experimental studies were all rated as of weak quality as they were rated as weak in both the study design and blinding domains. The EHPP tool defines weak quality studies as those with a rating of weak in two or more domains. Supplement C presents the quality of each included study for each component and global rating of quality. Figure 2 presents the summary of methodological quality of included studies. 


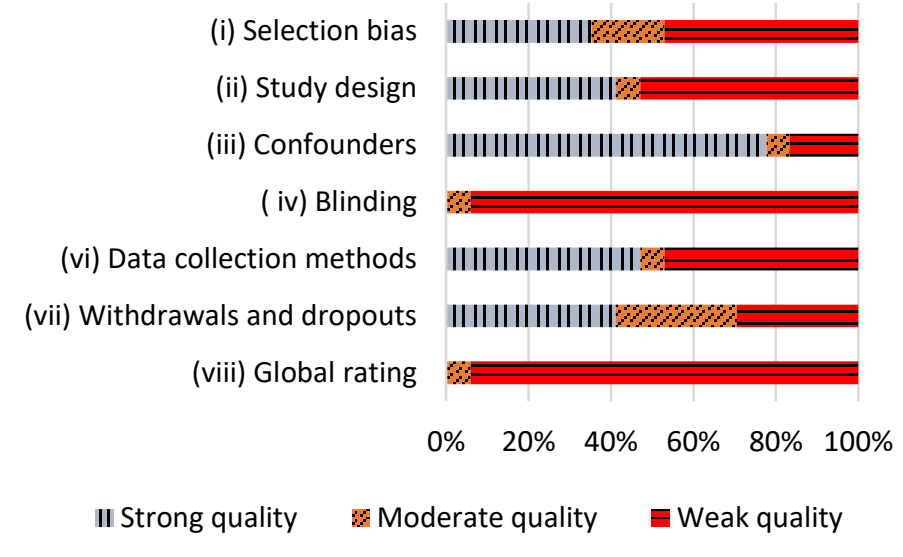

Figure 2. Summary of methodological quality of included studies.

\section{Intervention strategy assessment}

None of the review studies included all five of the Active Living by Design strategies from the model. Two studies included four strategies; Mendoza et al. (2009) did not include a 'policies' component, and Ostergaard et al. (2005) did not include a 'preparation' component. ${ }^{51,55}$ The majority of interventions used three strategies, and the most commonly used strategies were 'preparation', 'promotion' and 'programs'. The least used strategy was 'policies', closely followed by 'physical projects'. Two studies used one strategy, 'promotion', each.

\section{Effectiveness}

Of the 17 studies included in the review, 11 studies provided data for inclusion in the meta-analysis. The remaining studies outcome measures were inappropriate data types for meta-analysis. Figure 3 and 4 show forests plots of continuous and frequency data for active travel outcomes. Figure 5 shows a forest plot of the continuous data for physical fitness outcomes. Funnel plot asymmetry suggested publication bias may be present. 


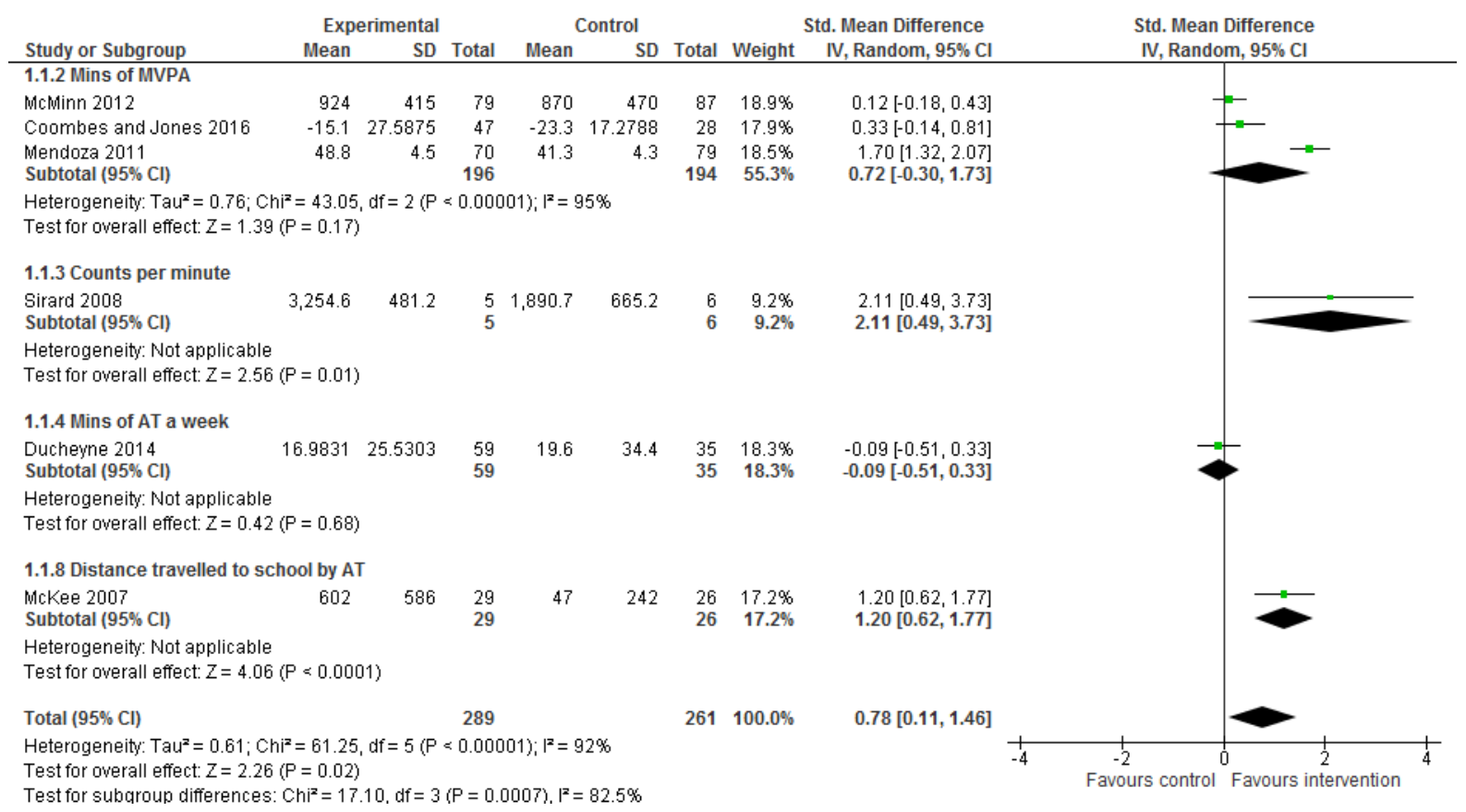

Figure 3. Forest plot of continuous active travel data (6 studies).

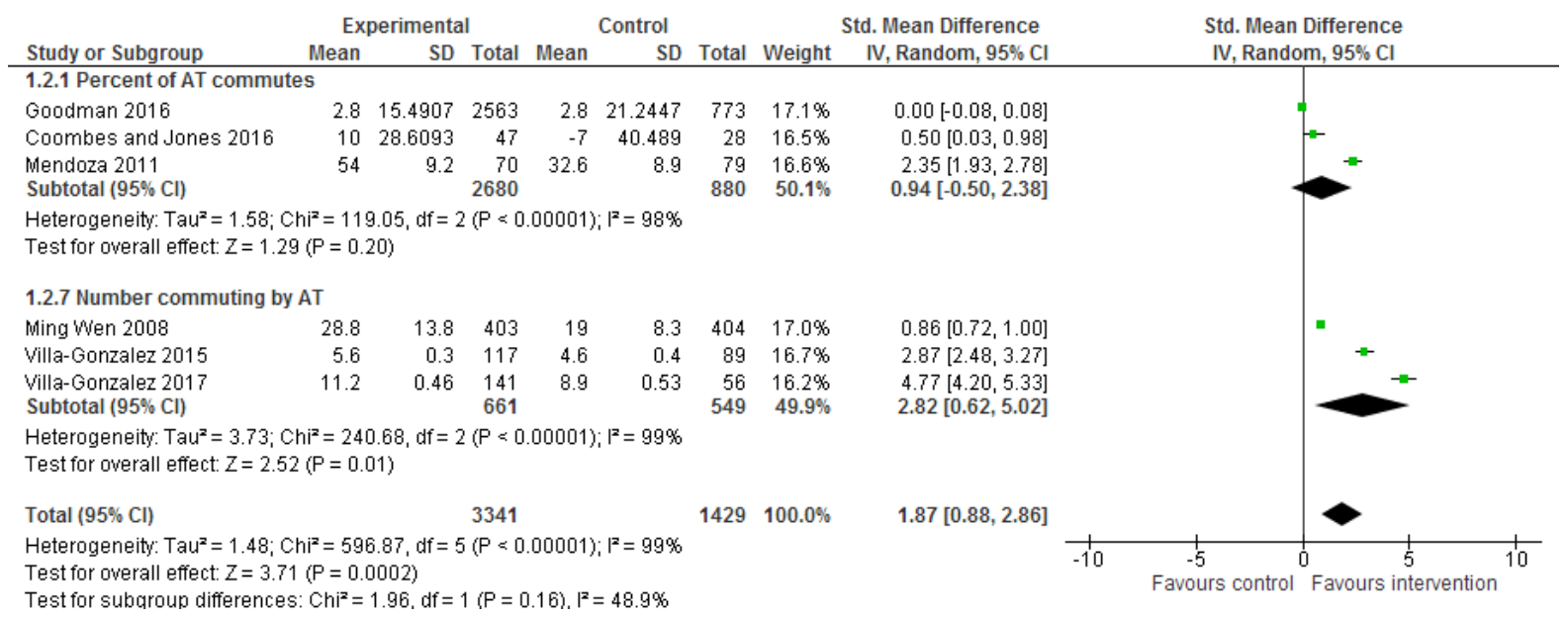

Figure 4. Forest plot of frequency active travel data (6 studies).

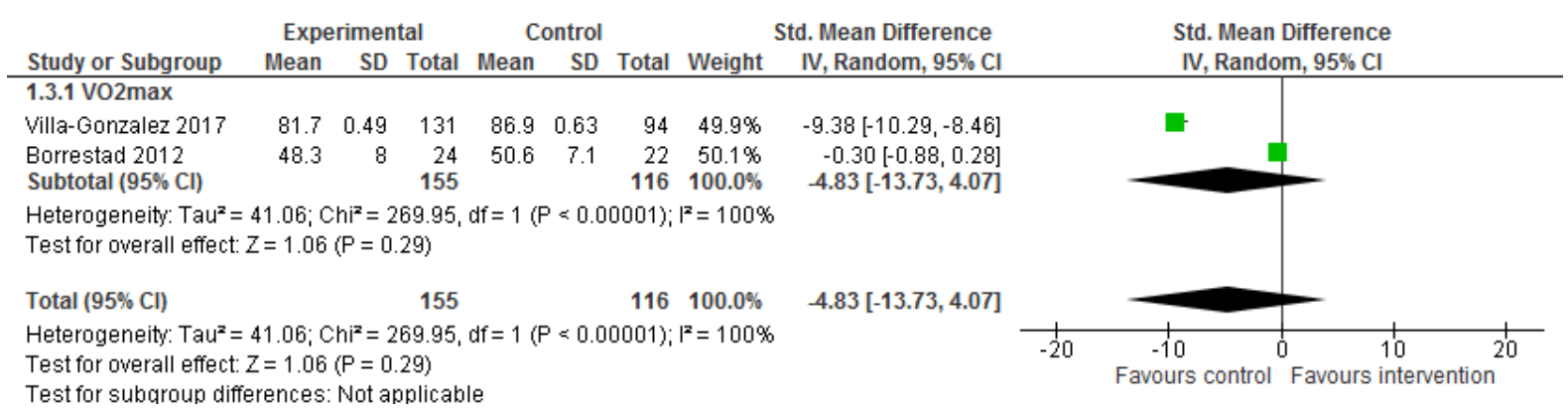

Figure 5. Forest plot of continuous physical fitness data (2 studies). 
Assessment of the effect of interventions on continuous active travel outcomes resulted in a statistically significant difference in favour of the intervention (SMD 0.78, 95\% CI 0.11-1.46, n=550) (Figure 3). The majority of studies had standardised mean differences in favour of the intervention, with only two study's results favouring the control. ${ }^{30,53}$ The confidence interval and $p$-value $(p=0.02)$ for overall effect shows a statistically significant effect favouring the intervention. The heterogeneity of the results was very high $\left(\mathrm{I}^{2}=92 \%\right)$, reducing the confidence in the consistency of the findings.

Frequency active travel outcomes (figure 4) had a range of standardised mean differences from 0.00 (-0.08, $0.08)$ to $4.77(4.20,5.33) .^{32,44}$ All studies favoured the intervention, with only one study showing no difference. ${ }^{43}$ The overall standardised mean difference for frequency active travel outcomes significantly favoured the intervention (SMD 1.87, 95\% CI 0.88-2.86, $\mathrm{n}=4770$ ). The heterogeneity of the frequency outcomes was very high $\left(\mathrm{I}^{2}=99 \%\right)$, decreasing the sureness of the consistency of the findings.

Continuous physical fitness outcomes (figure 5) had standardised mean differences ranging from -9.38 (-10.29, $8.46)$ to $-0.30(-0.88,0.28){ }^{32,52}$ The overall standardised mean difference favoured the control (SMD $-4.83,95 \%$ CI -13.73-4.07, $n=271)$. The overall effect was not statistically significant, indicated by the confidence intervals and $p$-value $(p=0.29)$. Both study's intervention included in this analysis focused upon education and encouragement. There were only two studies measuring cardiovascular fitness, reducing the applicability of these results to future public health practice. The heterogeneity was very high $\left(\mathrm{I}^{2}=100 \%\right)$.

\section{Cohen's D effect size}

Due to the large heterogeneity of the studies, few studies were able to be included in a meta-analysis at once. The calculation of Cohen's D effect size allowed the comparison of 14 included studies. It was not possible to calculate effect size for three studies due to missing data. ${ }^{44,49,55}$ The method of calculation and effect sizes are shown in Supplement D. The majority of study outcomes showed positive effect sizes ranging from trivial to very large. The range of effect sizes across all included studies was from -9.48 to 12.24 , with a mean effect size of $0.50( \pm 3.44)$ in favour of the intervention.

\section{Complexity assessment}

The complexity of each intervention was assessed using iCAT_SR (Table 1). There was significant diversity in the level of complexity of the included studies, global scores for complexity ranged from 11/30 to 23/30, with mean of $15.7( \pm 3.32)$. The most 'simple' intervention was a walking school bus, whereas the most complex intervention provided multiple components directed at varying levels (students, teachers, parents). ${ }^{47-48}$ The most common complexity rating was simple, with exception of component 8 (the degree to which the effects of the intervention are dependent on the context), which received the highest rating of moderately complex or complex. 


\begin{tabular}{|c|c|c|c|c|c|c|c|c|c|c|c|c|}
\hline & & (i) & (ii) & (iii) & (iv) & (v) & (vi) & (vii) & $\begin{array}{l}\text { (viii } \\
\text { ) }\end{array}$ & (ix) & $(\mathbf{x})$ & $\begin{array}{c}\text { Global } \\
\text { score } \\
(/ 30)\end{array}$ \\
\hline \multicolumn{2}{|c|}{ Borrestad et al. (2012) ${ }^{53}$} & 1 & 1 & 1 & 1 & 1 & 2 & 1 & 2 & 1 & 3 & 14 \\
\hline \multicolumn{2}{|c|}{ Bungum et al. $(2014)^{44}$} & 2 & 1 & 1 & 3 & 1 & 1 & 1 & 1 & 2 & 1 & 14 \\
\hline \multicolumn{2}{|c|}{ Coombes and Jones (2016) ${ }^{30}$} & 3 & 1 & 1 & 1 & 1 & 2 & 2 & 1 & 1 & 1 & 14 \\
\hline \multicolumn{2}{|c|}{ Ducheyne et al. (2014) ${ }^{54}$} & 2 & 2 & 2 & 1 & 1 & 1 & 1 & 3 & 1 & 1 & 15 \\
\hline \multicolumn{2}{|c|}{ Goodman et al. (2016) ${ }^{45}$} & 2 & 2 & 1 & 1 & 3 & 1 & 3 & 1 & 2 & 2 & 18 \\
\hline \multicolumn{2}{|c|}{ Groesz (2007) 46} & 2 & 3 & 2 & 1 & 3 & 1 & 3 & 3 & 1 & 2 & 21 \\
\hline \multicolumn{2}{|c|}{ Heelan et al. (2009) 50} & 1 & 1 & 1 & 1 & 1 & 1 & 1 & 3 & 1 & 1 & 12 \\
\hline \multicolumn{2}{|c|}{ Hoelscher et al. (2016) ${ }^{56}$} & 1 & 1 & 1 & 3 & 1 & 1 & 1 & 3 & 1 & 3 & 16 \\
\hline \multicolumn{2}{|c|}{ McKee et al. (2007) ${ }^{47}$} & 1 & 1 & 1 & 1 & 1 & 1 & 1 & 2 & 2 & 1 & 12 \\
\hline \multicolumn{2}{|c|}{ McMinn et al. (2012) ${ }^{43}$} & 2 & 3 & 1 & 3 & 2 & 1 & 1 & 1 & 2 & 2 & 18 \\
\hline \multicolumn{2}{|c|}{ Mendoza et al. (2009) ${ }^{51}$} & 3 & 1 & 1 & 1 & 1 & 1 & 1 & 3 & 1 & 1 & 14 \\
\hline \multicolumn{2}{|c|}{ Mendoza et al. (2011) 52} & 1 & 1 & 1 & 1 & 1 & 1 & 1 & 3 & 1 & 1 & 12 \\
\hline \multicolumn{2}{|c|}{ Ming Wen et al. (2008) ${ }^{48}$} & 3 & 1 & 2 & 2 & 2 & 2 & 3 & 3 & 3 & 2 & 23 \\
\hline \multicolumn{2}{|c|}{ Ostergaard et al. $(2015)^{55}$} & 3 & 2 & 1 & 3 & 1 & 2 & 1 & 2 & 2 & 3 & 20 \\
\hline \multicolumn{2}{|c|}{ Sirard et al. $(2008)^{49}$} & 1 & 1 & 1 & 1 & 1 & 1 & 1 & 2 & 1 & 1 & 11 \\
\hline \multicolumn{2}{|c|}{ Villa-Gonzalez et al. (2015) ${ }^{42}$} & 3 & 3 & 1 & 1 & 1 & 1 & 1 & 2 & 1 & 3 & 17 \\
\hline \multicolumn{2}{|c|}{ Villa-Gonzalez et al. (2017) ${ }^{32}$} & 3 & 2 & 1 & 1 & 1 & 1 & 1 & 1 & 1 & 3 & 15 \\
\hline & Mean & 2 & 1.6 & 1.4 & 1.5 & 1.4 & 1.2 & 1.4 & 2.1 & 1.4 & 1.8 & 15.7 \\
\hline & Mode & 1 & 1 & 1 & 1 & 1 & 1 & 1 & 3 & 1 & 1 & 14 \\
\hline \multicolumn{13}{|c|}{ Key: 1 - simple; 2 - moderately complex; 3 - complex. } \\
\hline (i) & \multicolumn{12}{|c|}{ Number of discrete, active components. } \\
\hline (ii) & \multicolumn{12}{|c|}{ Number of behaviours or actions of intervention recipients or participants to which the intervention is directed. } \\
\hline (iii) & \multicolumn{12}{|c|}{ Number of organisational levels targeted by the intervention. } \\
\hline (iv) & \multicolumn{12}{|c|}{ The degree of flexibility or tailoring permitted across sites or individuals in intervention implementation / application. } \\
\hline (v) & \multicolumn{12}{|c|}{ The level of skill required by those delivering the intervention. } \\
\hline (vi) & \multicolumn{12}{|c|}{$\begin{array}{l}\text { The level of skill required for the targeted behaviour when entering the study by those receiving the intervention in order to meet the intervention's } \\
\text { objectives. }\end{array}$} \\
\hline (vii) & \multicolumn{12}{|c|}{ The degree of interaction/independence between intervention components of intervention components. } \\
\hline (viii) & \multicolumn{12}{|c|}{ The degree to which the effects of the intervention are dependent on the context or setting. } \\
\hline (ix) & \multicolumn{12}{|c|}{ The degree to which the effects of the intervention are modified by participant or provider factors. } \\
\hline$(x)$ & The length of the causal patl & way be & $\mathrm{n}$ the in & ention an & the outc & & & & & & & \\
\hline
\end{tabular}

Table 1. Complexity summary graph.

Figure 6 presents the relationship between complexity and effectiveness by Cohen's D effect size, showing that there is no correlation. A Spearman's rank-order correlation assessed the relationship, resulting in a moderate negative non-significant relationship $(r=-0.270 ; p=0.351)$ suggesting, that for these interventions, there was no increased effectiveness with more complex interventions. 


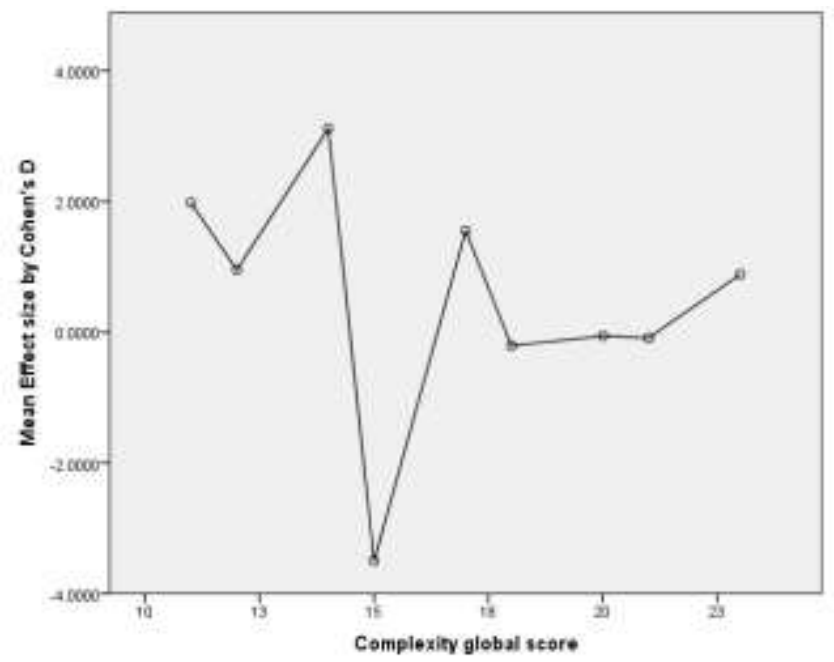

Figure 6. Scatter graph presenting complexity global score against effectiveness by Cohen's D effect size 


\section{$\underline{\text { Discussion }}$}

This review concluded that active travel interventions are effective at increasing PA in children. The effect was not observed for physical fitness, hypothesised to be due to the extremely limited available evidence. Active travel intervention studies included in this review were strongly heterogeneous in terms of intervention type and were of weak quality. Walking school buses and educational strategies were the most effective intervention types, with very few interventions using 'policies' despite strong evidence of effectiveness. ${ }^{59}$ No relationship between complexity and effectiveness was observed.

Conclusions of effectiveness and the overall weak quality of included studies are in line with the findings of the reviews conducted by Chillon et al. in 2011 and Villa-Gonzalez et al. in 2018. ${ }^{23-24}$ Comparison of review findings must be considered with caution due to the differing eligibility criteria such as the age of participants included and eligible study design types. Furthermore, the current review differed from previous as studies with a PA co-intervention were excluded to ensure the findings were the result of active travel promotion only. The included studies therefore differ greatly between the current and previous reviews. Chillon et al. evaluated 14 studies of children aged 6-18 years old; Villa-Gonzalez et al. followed the same procedure as the previously mentioned reviewed and included 23 studies. ${ }^{23}$ The current review included 17 studies despite applying more restrictive criteria, highlighting the increase in research in this field since 2011.

The current review shows that despite diversity of intervention types in individual studies, the overall effect is a promising increase in active travel to school, and this effect does not seem to be related to the complexity of the intervention. The included studies varied greatly in many aspects, including intervention type and duration, outcome measures, follow-up duration, and study locality. Review findings of effectiveness must be interpreted with caution due to the heterogeneity in the included studies. It should be noted that heterogeneity of the included studies was high (99-100\%), similar to the previous systematic review. ${ }^{23-24}$

A number of successful interventions provided a walking school bus (WSB), varying from simple WSB programme to a walking school bus alongside other activities/materials. Sub-group meta-analysis of WSB studies was not possible as one study did not provide sufficient data. Future research should ensure to provide complete data to allow the analysis of the pooled effect. Education based interventions (e.g. story reading, knowledge lessons) found success in improving active travel behaviours. Sub-group analysis (Figure 4) concluded a pooled effect of $2.82(0.62-5.02)$ in favour of the intervention. The success of these programmes was limited in comparison to walking school buses, possibly due to limited attention to the complex range of determinants (e.g. family, social, environmental). Future studies are needed to assess the additional benefit of combining the successful elements of WSBs and educational interventions to increase the impact on active travel outcomes.

Assessment of the intervention strategies concluded that intervention research to date is insufficient at including the recommended 'Active Living by Design' elements. No consistent relationship could be determined between intervention strategy (5Ps) use and effectiveness. The inconsistent relationship indicates a need for further research. The framework used lacks the capacity to distinguish between 'active' or 'inactive' intervention strategies. Future research should consider the 'active' or 'inactive' nature of an intervention component as this may play an important role in effectiveness. The most commonly used strategies were 'preparation', 'promotion' and 'programs', with 'policies' and 'physical projects' as the least used strategies. Only two included studies explicitly referred to the use of active travel policy, despite active travel policies being shown to be highly likely to produce large individual health benefits, as well as reductions in air and noise pollutions. ${ }^{59}$

No previous research has explored the complexity of active travel interventions. Assessing the relationship between effectiveness and complexity suggested that there was no significant correlation. Therefore complexity may not be a key indicator of success within active travel interventions. The conclusion regarding the relationship between complexity and effectiveness must be considered with caution due to limitations of assessment. Further research is necessary to explore this relationship further, utilising rigorous techniques and controlling for external influences.

The review findings have the potential to influence the field of public health. Although the decline in childhood PA may not be solely addressed through enhanced active travel, the findings show promise to positively impact children's behaviours. Walking school buses are a promising method of increasing PA and active commuting rates in children, with educational strategies also showing success. 
It is recommended for schools aiming to increase active commuting rates to implement walking school buses alongside educational strategies. More research is required in the field to allow stronger and more reliable review findings. Future studies should compare the effectiveness of active travel intervention components and durations to determine those that are most successful. Future research should assess the effectiveness of active travel policies, as well as investigating sustainability of health effects. All future intervention studies should seek to use robust controlled methodology.

\section{Study limitations and strengths}

The review findings add substantially to the active travel intervention evidence base. The previous reviews included non-experimental designs due to a lack of high quality research at the time. ${ }^{23-24}$ The growth of active travel research allowed the current review to include only controlled experimental designs, increasing the strength of the review findings. However there were a number of limitations to be noted. The high heterogeneity in study designs and outcomes increases the complexity of summarising effectiveness, whilst weak study quality and the use of self-reported methods to assess changes in PA reduces the strength and reliability of study findings. The wide ranging types of intervention made comparison of study findings difficult. Generalisation of the review's summary evidence is limited by these factors. Furthermore, the exclusion of non-English language studies may result in incomplete representation of the relevant literature.

\section{Conclusions}

The review's primary aim was to summarise the effectiveness of active travel interventions on active travel rates and physical fitness in primary school children. The review found that active travel interventions are successful at increasing rates of active commuting to school in primary school children, yet did not find success for increases in physical fitness, hypothesised to be due to the extremely limited available evidence. Further research is required to strengthen review findings. Studies of active travel policies, intervention types, active intervention ingredients and outcome sustainability are necessary. Future intervention studies should apply more rigorous methods to improve research quality. Representative samples, larger sample sizes, randomised controlled designs and valid and reliable measures should be a priority within future active travel research.

\section{Acknowledgements}

We would like to acknowledge Hidde van de Ploeg (Amsterdam UMC) and Caroline Heary (NUI Galway) for their input in protocol design.

Conflict of Interest statement: The authors declare that there are no conflicts of interest. 


\section{References}

1. Vaisto J, Haapala EA, Viitasalo A, Schnurr TM, Kilpelainen TO, Karjalainen P, Westgate K, Lakka HM, Laaksonen DE, Ekelund U, Brage S, Lakka TA. Longitudinal associations of physical activity and sedentary time with cardiometabolic risk factors in children. Scandinavian Journal of Medicine and Science in Sports 2019; 29(1): 113-123.

2. Abadie BR, Brown SP. Physical activity promotes academic achievement and a healthy lifestyle when incorporated into early childhood education. Forum on Public Policy 2010; 2010(5): 1-8.

3. Rasmussen M, Laumann K. The academic and psychological benefits of exercise in healthy children and adolescents. Eur J Psychol Educ 2013; 28(3): 945-962.

4. Cheung SY, Mak JY, Chan J. Children's physical activity participation and psychological wellbeing. Res Q Exerc Sport 2008; 79(S1): A30.

5. Parfitt F, Pavey T, Rowlands AV. Children's physical activity and psychological health: The relevance of intensity. Acta Pediatr 2009; 98(6): 1037-1043.

6. Tomson LM, Rangrazi RP, Friedman G, Hutchinson N. Childhood depressive symptoms, physical activity and health related fitness. J Sport Exerc Psychol 2003; 25(4): 419-439.

7. Parfitt G, Eston RG. The relationship between children's habitual activity level and psychological wellbeing. Acta Paediatr 2005; 94(12): 1791-1797.

8. $\quad$ NHS (2016). Are our kids moving with the times?: The 2016 Ireland North and South Report Card on Physical Activity for Children and Youth [online]. Last accessed 30 January 2017 at http://www.thehealthwell.info/sites/default/files/documents/TreetopStudio_Child_Advocacy_Document_ FINAL.pdf

9. Sullivan RA, Kuzel AH, Vaandering ME, Chen W. The association of physical activity and academic behaviour: a systematic review. J Sch Health 2017; 87(5): 388-398.

10. NHS Digital: National Statistics. Statistics on obesity, physical activity and diet. https://www.gov.uk/government/uploads/system/uploads/attachment_data/file/613532/obes-phys-actidiet-eng-2017-rep.pdf(accessed 25 July 2017).

11. Scholes S. Health survey for England 2015: Physical activity in children. http://www.content.digital.nhs.uk/catalogue/PUB22610/HSE2015-Child-phy-act.pdf (accessed 25 July 2017).

12. Ekelund U, Tomkinson G, Armstrong N. What proportion of youth are physically active? Measurement issues, levels and recent time trends. Br J Sports Med 2011; 45(11): 859-865.

13. Sustrans. Active travel: Related academic evidence. https://www.sustrans.org.uk/sites/default/files/images/files/Summary\%20of\%20active\%20travel\%20pro jects\%282\%29.pdf (accessed 06 August 2017)

14. Public Health England. What works in schools and colleges to increase physical activity. https://www.gov.uk/government/publications/what-works-in-schools-to-increase-physical-activitybriefing (accessed 06 August 2017)

15. NICE. Physical activity: walking and cycling. https://www.nice.org.uk/guidance/PH41/chapter/1Recommendations\#schools-workplaces-and-the-nhs (accessed 06 August 2017) 
16. Department of Health, Physical Activity, Health Improvement and Protection. Start Active, Stay Active: A report on physical activity from the four home countries' Chief Medical Officers. https://www.gov.uk/government/uploads/system/uploads/attachment_data/file/216370/dh_128210.pdf (accessed 18 July 2017).

17. Saunders LE, Green JM, Petticrew MP, Steinbach R, Roberts H. What are the health benefits of active travel? A systematic review of trials and cohort studies. PLoS One 2013; 8(8); e69912.

18. Pate RR, Flynn JI, Dowda M. Policies for promotion of physical activity and prevention of obesity in adolescence. J Exerc Sci Fit 2016; 14(2): 47-53.

19. Institute of Medicine. (2013). Educating the student body: Taking physical activity and physical education to school. Washington, DC: The National Academies Press.

20. Fyhri A, Hjorthol R, Mackett RL, Nordgaard Fotel T, Kytta M. Children's active travel and independent mobility in four countries: Development, social contributing trends and measures. Transport Policy 2011; 18(5): 703-710.

21. Garrard J. Active transport: Children and young people. An overview of recent evidence. https://www.vichealth.vic.gov.au/media-and-resources/publications/active-transport-children (accessed 28 July 2017)

22. Healthy Ireland. Get Ireland active: National physical activity plan for Ireland. http://health.gov.ie/wpcontent/uploads/2016/01/Get-Ireland-Active-the-National-Physical-Activity-Plan.pdf (accessed 23 June 2017).

23. Chillon P, Evenson KR, Vaughn A, Ward DS. A systematic review of interventions for promoting active transportation to school. Int J Behav Nutr Phys Act 2011; 8(10).

24. Villa-Gonzalez E, Barranco-Ruiz Y, Evenson KR, Chillon P. Systematic review of interventions for promoting active school transport. Preventive Medicine 2018: 111: 115-134.

25. PRISMA. PRISMA: Transparent reporting of systematic reviews and meta-analyses. http://www.prisma-statement.org/(accessed 24 June 2017).

26. Ogilvie D., Egan M, Hamilton V, Petticrew M. Promoting walking and cycling as an alternative to using cars: systematic review. BMJ 2014; 329: 763-766.

27. Pont K, Ziviani J, Wadley D, Bennett S, Abbott R. Environmental correlates of children's active transportation: a systematic literature review. Health Place 2009; 15: 827-840

28. Shadish WR, Cook TD, Campbell DT. Experimental and quasi-experimental designs for generalised causal inference. Boston, Mass: Houghton Mifflin Company, 2002.

29. Craig P, Cooper C, Gunnell D, Haw S, Lawson K, Macintyre S, Ogilvie D, Petticrew M, Reeves B, Sutton M, Thompson S. Using natural experiments to evaluate population health interventions: new Medical Research Council guidance. J Epidemiol Community Health. 2012; 66(12): 1182-6.

30. Coombes E, Jones A. Gamification of active travel to school: a pilot evaluation of the Beat the Street physical activity intervention. Health \& Place 2016; 39: 62-69.

31. Mammen G, Stone M, Faulkner G, Ramanathan S, Buliung R, Kennedy J, et al. Active school travel: An evaluation of the Canadian school travel planning intervention. Prev Med 2014; 60: 6055-59.

32. Villa-Gonzalez E, Ruiz J, Mendoza J, Chillon P. Effects of a school-based intervention on active commuting to school and health-related fitness. BMC Public Health 2017; 17: 20. 
33. McDonald N, Yang Y, Abbott S, Bullock A. Impact of the Safe Routes to School program on walking and biking: Eugene, Oregon study. Transport Policy 2013; 29: 243-248.

34. ProQuest. RefWorks. https://www.refworks.com/refworks/default.aspx?r=authentication::init (accessed 28 $8^{\text {th }}$ March 2017)

35. Higgins JPT, Green S (editors). Cochrane Handbook for Systematic Reviews of Interventions Version 5.1.0 [updated March 2011]. The Cochrane Collaboration, 2011. Available from www.handbook.cochrane.org.

36. Effective Public Health Practice Project. Quality Assessment Tool for Quantitative Studies: Effective Public Health Practice Project. http://www.ephpp.ca/PDF/Quality\%20Assessment\%20Tool_2010_2.pdf(accessed 13 June 2017)

37. Bors P, Dessauer M, Bell R, Wilkerson R, Lee J, Strunk S. The Active Living by Design national program: community initiatives and lessons learned. Am J Prev Med 2009; 37(6 Supplement 2): S313S321.

38. Brennan LK, Brownson RC, Hovmand P. Evaluation of Active Living by Design: Implementation patterns across communities. Am J Prev Med 2012; 43(5 Supplement 4): S351-S366.

39. Fesperman CE, Evenson KR, Rodriguez DA, Salvesen D: A comparative case study on active transport to and from school. Prev Chronic Dis 2008, 5: A40.

40. Lewin S, Hendry M, Chandler J, Oxman AD, Michie S, Shepperd S et al. Guidance for using the iCAT_SR: Intervention Complexity Assessment Tool for Systematic Reviews. http://methods.cochrane.org/sites/default/files/public/uploads/icat_sr_additional_file_4_2016_12_27.p df (accessed 13 June 2017)

41. Kim H-Y. Statistical notes for clinical researchers: effect size. Restor Dent Endod 2015; 40(4): 328331.

42. Villa-Gonzalez E, Ruiz JR, Ward DS, Chillon P. Effectiveness of an active commuting school-based intervention at 6-month follow-up. Eur J Public Health 2015; 26 (2): 272-276

43. McMinn D, Rowe DA, Murtagh S, Nelson NM. The effect of a school-based active commuting intervention on children's commuting physical activity and daily physical activity. Prev Med 2012; 54(5): 316-318.

44. Bungum TJ, Clark S, Aguilar B. The effect of an active transport to school intervention at a suburban elementary school. Am J Health Behav 2014; 45(4): 205-209.

45. Goodman A, van Sluijs EMF, Ogilvie D. Impact of offering cycle training in schools upon cycling behaviour: a natural experimental study. Int J Behav Nutr 2016; 13(1): 34.

46. Groesz LM. A conceptual evaluation of a school-based utilitarian exercise model [Doctor of Philosophy]. The University of Texas at Austin; 2008.

47. McKee R, Mutrie N, Crawford F, Green B. Promoting walking to school: results of a quasiexperimental trial. J Epidemiol Community Health 2007; 61: 818-823.

48. Ming Wen L, Fry D, Merom D, Rissel C, Dirkis H, Balafas A. Increasing active travel to school: are we on the right track? A cluster randomised controlled trial from Sydney, Australia. Prev Med 2008; 47 : 612-618. 
49. Sirard JR, Alhassan S, Spencer TR, Robinson TN. Changes in physical activity from walking to school. J Nutr Educ Behav 2008; 40: 324-326.

50. Heelan KA, Abbey BM, Donnelly JE, Mayo MS, Welk GJ. Evaluation of a walking school bus for promoting physical activity in youth. J Phys Act Health 2009; 6: 560-567.

51. Mendoza JA, Levinger DD, Johnson BD. Pilot evaluation of a walking school bus program in a lowincome, urban community. BMC Public Health 2009; 9: 818-823.

52. Mendoza JA, Watson K, Baranowski T, Nicklas TA, Uscanga DK, Hanfling MJ. A walking school bus and children's physical activity: a pilot cluster randomized controlled trial. Pediatrics 2011; 128(3): e537.

53. Borrestad LAB, Ostergaard L, Andersen LB, Bere E. Experiences from a randomised, controlled trial on cycling to school: does cycling increase cardiorespiratory fitness?. Scand J Public Health 2012; 40: 245-252.

54. Ducheyne F, De Bourdeaudhuij I, Lenior M, Cardon M. Effects of a cycle training course on children's cycling skills and levels of cycling to school. Health \& Place 2014; 67: 49-60.

55. Ostergaard L, Toftegaard Stockel J, Anderson LB. Effectiveness and implementation of interventions to increase commuter cycling to school: a quasi-experimental study. BMC Public Health 2015; 15: 1199.

56. Hoelscher D, Ory M, Dowdy D, Miao J, Atteberry H, Nichols D, et al.. Effects of funding allocation for safe routes to school programs on active commuting to school and related behavioural, knowledge, and psychosocial outcomes: results from the Texas childhood obesity prevention policy evaluation (TCOPPE) study. Environ Behav 2016; 48(1): 210-229.

57. Moher D, Liberati A, Tetzlaff J, Altman DG, The PRISMA Group. Preferred Reporting Items for Systematic Reviews and Meta-Analyses: The PRISMA Statement. Open Med 2009; 3(3): 123-130.

58. National Collaborating Centre for Primary Care (UK). Medicines adherence: involving patients in decisions about prescribed medicines and supporting adherence. London: Royal College of General Practitioners (UK); 2009 Jan. (NICE Clinical Guidelines, No. 76.) 7, Assessment of adherence. https://www.ncbi.nlm.nih.gov/books/NBK55447/(accessed 25 th August 2017)

59. de Nazelle A, Nieuwenhuijsen MJ, Anto JM, Brauer M, Briggs D, Braun-Fahrlander C et al. Improving health through policies that promote active travel: A review of evidence to support integrated health impact assessment. Environ Int 2011; 37(4): 766-777. 


\section{Supplement A: Search strategy}

Four categories of search terms were identified:

1) Active transportation,

2) Interventions,

3) Age,

4) Study design.

The electronic search was conducted in 4 databases:

1. Medline:

WALKING/ OR BICYCLING/ OR (activ*adj5 (travel* or transport*)) OR "walk to school*" OR "safe routes to school*" OR "walking school?bus*" OR "walk* bus*") and (exp HEALTH PROMOTION/ OR PUBLIC HEALTH/ OR intervention* OR initiative* OR implement* OR project* OR pilot* OR scheme*) AND (CHILD/ OR CHILD HEALTH/ OR "primary school*" OR "elementary school*" OR "infant school*" OR "junior school*") AND ("randomi\#ted control*" OR controlled OR trial* OR randomly))

\section{EMBASE:}

WALKING/ OR CYCLING/ OR (activ* adj5 (travel* or transport*)) OR "walk to school*" OR "safe routes to school*" OR "walking school?bus*" OR "walk* bus*") and (exp HEALTH PROMOTION/ OR PUBLIC HEALTH CAMPAIGN/ OR PUBLIC HEALTH/ OR HEALTH EDUCATION/ OR intervention* OR initiative* OR implement* OR project* OR pilot* OR scheme*) AND (CHILD/ OR CHILD HEALTH/ OR PRIMARY SCHOOL/ OR ((elementary or infant* or junior*) adj5 school*)) AND ("RANDOMIZED CONTROLLED TRIAL (TOPIC)"/ OR "randomi\#ed control*" OR controlled OR trial* OR randomly))

3. PsycINFO:

(EXERCISE/ or TRAVELLING/ or WALKING/ or PHYSICAL ACTIVITY/ or "COMMUTING (TRAVEL)"/ or (activ* adj5 (travel* or transport*)).mp. or "walk to school*".mp. or "safe routes to school*".mp. or "walking school?bus*".mp. or "walk* bus*".mp.) and (INTERVENTION/ or SCHOOL BASED INTERVENTION/ or exp HEALTH PROMOTION/ or PUBLIC HEALTH/ or intervention*.mp. or initiative*.mp. or implement*.mp. or project*.mp. or pilot*.mp. or scheme*.mp.) and (("primary school*" or "elementary school*" or "infant school*" or "junior school*").mp. or school*.ti,ab.) and ("randomi\#ed control*" or controlled or trial* or randomly).mp. [mp=title, abstract, heading word, table of contents, key concepts, original title, tests \& measures]

4. Web of Science: 
$\mathrm{TS}=\left(\right.$ walk$\left.^{*}\right) \mathrm{OR} \mathrm{TS}=($ cycl*$)$ OR TS= $($ activ* near/2 $($ travel $*$ or transport $*)) \mathrm{OR} \mathrm{TS}=("$ walk to school*" or "safe routes to school*" or "walking school\$bus*" or "walk* bus*") AND TOPIC: (intervention* or initiative* or implement* or project* or pilot* or scheme*) OR TOPIC: ("health promotion*") OR TOPIC: ("public health*") AND TOPIC: (child*) OR TOPIC: ((primary or elementary or infant* or junior*) near/5 school*) AND TOPIC: ("randomi?ed control*") OR TOPIC: (controlled or trial* or randomly)

\section{TRIS:}

(walk* OR cycl* OR activ* (travel* or transport*) OR "walk to school*" OR "safe routes to school*" OR "walking school bus*" OR "walk* bus") AND (intervention* OR initiative* OR implement* OR project* OR pilot* OR scheme* OR "health promot*" OR "public health") AND (child* OR primary OR elementary OR infant* OR junior* OR school*) AND (random* OR control* OR trial*) 


\begin{tabular}{|c|c|c|c|c|c|}
\hline $\begin{array}{l}\text { Study author } \\
\text { and year }\end{array}$ & Methods & Participants & Intervention & Outcomes & Notes \\
\hline $\begin{array}{l}\text { Borrestad et } \\
\text { al. }(2012)^{53}\end{array}$ & $\begin{array}{l}\text { Design: RCT } \\
\text { Country } \\
\text { (locality): } \\
\text { Norway }\end{array}$ & $\begin{array}{l}\text { Setting: School based } \\
\text { Intervention group: } 26 \text { students in } \\
\text { Kristiansand community }- \text { living less } \\
\text { than } 5 \mathrm{~km} \text { from school, access to } \\
\text { bicycle, not cycling to school in last } 3 \\
\text { months. } \\
\text { Control group: } 27 \text { students in } \\
\text { Kristiansand community }- \text { living less } \\
\text { than } 5 \mathrm{~km} \text { from school, access to } \\
\text { bicycle, not cycling to school in last } 3 \\
\text { months. } \\
\text { Age: } 10-13 \text { years old. Mean } 10.8 \text { years } \\
( \pm 0.7) \text {. } \\
\text { Gender: } 47.1 \% \text { female, } 52.9 \% \text { male } \\
\text { Ethnicity: Not stated }\end{array}$ & $\begin{array}{l}\text { Name of intervention: N/A } \\
\text { Duration: } 12 \text { weeks. } \\
\text { Components: Intervention group } \\
\text { encouraged to cycle to school. } 30 \text { minute } \\
\text { group sessions every other week } \\
\text { focusing on raising awareness, health } \\
\text { benefits and helping parents support. } \\
\text { Control group received healthy eating } \\
\text { program for } 2 \text { years. }\end{array}$ & $\begin{array}{l}\text { Primary outcome: } \\
\text { Cardiovascular fitness } \\
\left(\mathrm{VO} 2_{\max }\right) \text {. } \\
\text { Number of follow-ups: } 2 \\
\text { Follow up time points: } \\
\text { Baseline and 2 years }\end{array}$ & $\begin{array}{l}\text { Conflict } \\
\text { interest: No } \\
\text { Funding source: } \\
\text { University } \\
\text { Agder }\end{array}$ \\
\hline $\begin{array}{l}\text { Bungum et al. } \\
(2014)^{44}\end{array}$ & $\begin{array}{l}\text { Design: Quasi- } \\
\text { experimental } \\
\text { Country } \\
\text { (locality): USA }\end{array}$ & $\begin{array}{l}\text { Setting: School based } \\
\text { Intervention group: } 66 \text { students at } \\
\text { baseline at } 1 \text { school participating in } \\
\text { Nevada Moves Day. } \\
\text { Control group: } 78 \text { students at baseline } \\
\text { at } 1 \text { school not participating in Nevada } \\
\text { Moves Day. } \\
\text { Age: In K5 grade - no specific age } \\
\text { range stated. } \\
\text { Gender: } 43.8 \% \text { female, } 56.2 \% \text { male } \\
\text { Ethnicity: Not stated. }\end{array}$ & $\begin{array}{l}\text { Name of intervention: Nevada Moves } \\
\text { Day } \\
\text { Duration: } 1 \text { day plus promotion prior. } \\
\text { Components: NMD schools allowed to } \\
\text { promote intervention as they wish. } \\
\text { Intervention school used following } \\
\text { strategies: } \\
\text { Morning announcements; } \\
\text { Letter to parents; } \\
\text { Telephone message to parents; } \\
\text { Marquis advertisement; } \\
\text { Teacher promotion; } \\
\text { Sticker for students actively travelling. } \\
\text { Control group received no intervention. }\end{array}$ & $\begin{array}{l}\text { Primary outcome: Mode of } \\
\text { travel to school } \\
\text { Number of follow-ups: } 3 \\
\text { Follow up time points: } 1 \\
\text { week prior, on NMD, and } 1 \\
\text { week after. }\end{array}$ & $\begin{array}{l}\text { Conflict of } \\
\text { interest: No } \\
\text { Funding source: } \\
\text { Not stated. }\end{array}$ \\
\hline $\begin{array}{l}\text { Coombes and } \\
\text { Jones (2016) } \\
30\end{array}$ & $\begin{array}{l}\text { Design: } \\
\text { Controlled trial } \\
\text { Country }\end{array}$ & $\begin{array}{l}\text { Setting: School based } \\
\text { Intervention group: } 51 \text { students in } \\
\text { year } 4 \text { and } 5 \text { at } 1 \text { school. }\end{array}$ & $\begin{array}{l}\text { Name of intervention: Beat the Street } \\
\text { Duration: } 9 \text { weeks } \\
\text { Components: Beat boxes installed in }\end{array}$ & $\begin{array}{l}\text { Primary outcome: Mode of } \\
\text { travel to school } \\
\text { Number of follow-ups: } 3\end{array}$ & $\begin{array}{l}\text { Conflict of } \\
\text { interest: No } \\
\text { Funding source: }\end{array}$ \\
\hline
\end{tabular}




\begin{tabular}{|c|c|c|c|c|c|}
\hline Study author & Methods & Participants & Intervention & Outcomes & Notes \\
\hline & (locality): UK & $\begin{array}{l}\text { Control group: } 29 \text { students in year } 4 \\
\text { and } 5 \text { at } 1 \text { school } 7.5 \mathrm{~km} \text { away from } \\
\text { intervention school. } \\
\text { Age: } 8-10 \text { years old (Intervention: } \\
66.7 \% \text { in year } 4 \text {; Control: } 44.8 \% \text { in } \\
\text { year 4). } \\
\text { Gender: Intervention: } 62.7 \% \text { female; } \\
\text { Control: } 41.4 \% \text { female. } \\
\text { Ethnicity: Not stated. }\end{array}$ & $\begin{array}{l}\text { street environment. Students awarded } \\
\text { when touch smartcard on sensor. } \\
\text { Target setting } \\
\text { Between school competitions } \\
\text { Group level competitions } \\
\text { Promotion events } \\
\text { Control group received no intervention. }\end{array}$ & $\begin{array}{l}\text { Follow up time points: } \\
\text { Baseline, week } 7 \\
\text { and week } 20 \text { (during) }\end{array}$ & $\begin{array}{l}\text { CEDAR }- \text { UK } \\
\text { Clinical Research } \\
\text { Collaboration }\end{array}$ \\
\hline $\begin{array}{l}\text { Ducheyne et } \\
\text { al. (2014) }\end{array}$ & $\begin{array}{l}\text { Design: RCT } \\
\text { Country } \\
\text { (locality): } \\
\text { Belgium }\end{array}$ & $\begin{array}{l}\text { Setting: School based } \\
\text { Intervention group: } \\
\text { Group } 1 \text { (Intervention): } 25 \text { students in } \\
4^{\text {th }} \text { grade at } 1 \text { school in Flanders, } \\
\text { Belgium. } \\
\text { Group } 2 \text { (Intervention+Parents): } 34 \\
\text { students in } 4^{\text {th }} \text { grade and their parents at } \\
1 \text { school in Flanders, Belgium. } \\
\text { Control group: } 35 \text { students in } 4^{\text {th }} \text { grade } \\
\text { at } 1 \text { school in Flanders, Belgium. } \\
\text { Age: } 9-10 \text { years old (Mean } 9.33 \text { years } \\
\text { old }( \pm 0.5) \text { ). } \\
\text { Gender: } 52.17 \% \text { female, } 47.83 \% \text { male. } \\
\text { Ethnicity: Not stated. }\end{array}$ & $\begin{array}{l}\text { Name of intervention: N/A } \\
\text { Duration: } 1 \text { month } \\
\text { Components: Intervention group } \\
\text { received cycle training consisting of } 4 \\
\text { sessions. Intervention+Parents group } \\
\text { received cycling training with } 4 \text { sessions } \\
\text { and parental involvement tasks. Control } \\
\text { group received no intervention. }\end{array}$ & $\begin{array}{l}\text { Primary outcome: Minutes } \\
\text { cycling to school per week } \\
\text { Number of follow-ups: } 3 \\
\text { Follow up time points: } \\
\text { Baseline, post-intervention, } \\
\text { and } 5 \text { months. }\end{array}$ & $\begin{array}{l}\text { Conflict of } \\
\text { interest: No } \\
\text { Funding source: } \\
\text { Lifeline campaign } \\
\text { of the Research } \\
\text { Foundation, } \\
\text { Flanders FWOAL }\end{array}$ \\
\hline
\end{tabular}




\begin{tabular}{|c|c|c|c|c|c|}
\hline $\begin{array}{l}\text { Study author } \\
\text { and year }\end{array}$ & Methods & Participants & Intervention & Outcomes & Notes \\
\hline $\begin{array}{l}\text { Goodman, } \\
\text { van Sluijs and } \\
\text { Ogilvie (2016) } \\
45\end{array}$ & 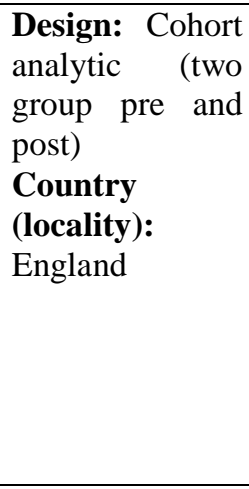 & $\begin{array}{l}\text { Setting: School based } \\
\text { Intervention group: } 2563 \text { children } \\
\text { from Millennium Cohort Study } \\
\text { Control group: } 773 \text { children from } \\
\text { Millennium Cohort Study. } \\
\text { Age: } 10-11 \text { years; } 36 \% 10 \text { years, } 64 \% \\
11 \text { years } \\
\text { Gender: } 50 \% \text { female, } 50 \% \text { male } \\
\text { Ethnicity: } 86 \% \text { White, } 3 \% \text { Mixed, } 9 \% \\
\text { South Asian }\end{array}$ & $\begin{array}{l}\text { Name of intervention: Bikeability } \\
\text { Duration: } 1 \text { month }-4 \text { sessions lasting } 2 \\
\text { hours. } \\
\text { Components: Cycle training scheme to } \\
\text { give children both practical skills and } \\
\text { understanding of how to cycle on roads. } \\
\text { Scheme has } 3 \text { levels: Level } 1-\text { off road } \\
\text { training, Level } 2-\text { on road training, } \\
\text { Level } 3-\text { advanced on road training. } \\
\text { Level } 3 \text { rarely delivered at Primary } \\
\text { school level. Control group received no } \\
\text { intervention. }\end{array}$ & $\begin{array}{l}\text { Primary outcome: Cycling } \\
\text { behaviour - 'Child ever } \\
\text { cycles', 'Child usually } \\
\text { travels to school by bike' } \\
\text { Number of follow-ups: } 2 \\
\text { Follow up time points: } \\
\text { Baseline and median } 5 \\
\text { months. }\end{array}$ & $\begin{array}{l}\text { Conflict of } \\
\text { interest: No } \\
\text { Funding source: } \\
\text { Economic and } \\
\text { Social Research } \\
\text { Council (ESRC) }\end{array}$ \\
\hline $\begin{array}{l}\text { Groesz (2007) } \\
\text { G6 }\end{array}$ & $\begin{array}{l}\text { Design: } \\
\text { Controlled trial } \\
\text { Country } \\
\text { (locality): USA }\end{array}$ & $\begin{array}{l}\text { Setting: School based } \\
\text { Intervention group: } 74 \text { students in } 4^{\text {th }} \\
\text { or } 5^{\text {th }} \text { grade from } 4 \text { schools in medium } \\
\text { sized southwestern city. } \\
\text { Control group: } 45 \text { students in } 4^{\text {th }} \text { or } 5^{\text {th }} \\
\text { grade from } 3 \text { schools in medium sized } \\
\text { southwestern city. } \\
\text { Age: } 9.16-12.04 \text { years old (Mean } \\
10.41 \text { years old }( \pm 0.64) \text { ). } \\
\text { Gender: } 59.3 \% \text { female, } 40.3 \% \text { male. } \\
\text { Ethnicity: } \quad 61.40 \% \quad \text { White, } 17.5 \% \\
\text { Hispanics, } 10.53 \% \text { Blacks, } 7.1 \% \text { Other, } \\
2.63 \% \text { Native Americans, } 0.98 \% \text { Asian } \\
\text { American }\end{array}$ & $\begin{array}{l}\text { Name of intervention: BikeTexas Safe } \\
\text { Routes to School } \\
\text { Duration: } 2 \text { years } \\
\text { Components: } \\
\text { Educational component: } 15 \text { lessons } \\
\text { during } 6 \text { hours of training - safety, laws } \\
\text { and bike/body maintenance. } \\
\text { Curriculum handouts. } \\
\text { Encouragement - e.g. contests. } \\
\text { Control group received no intervention. }\end{array}$ & $\begin{array}{l}\text { Primary outcome: } \\
\text { Concurrent ten-day bicycling } \\
\text { and walking to school; } \\
\text { Retrospective five-day } \\
\text { bicycling and walking to } \\
\text { school. } \\
\text { Number of follow-ups: } 2 \\
\text { Follow up time points: } \\
\text { Baseline and } 7 \text { months. }\end{array}$ & $\begin{array}{l}\text { Conflict of } \\
\text { interest: No } \\
\text { Funding source: } \\
\text { The University of } \\
\text { Texas at Austin. }\end{array}$ \\
\hline $\begin{array}{l}\text { Heelan et al. } \\
(2009)^{50}\end{array}$ & $\begin{array}{l}\text { Design: Quasi- } \\
\text { experimental } \\
\text { Country } \\
\text { (locality): USA }\end{array}$ & $\begin{array}{l}\text { Setting: School based } \\
\text { Intervention group: } 201 \text { students in } 1^{\text {st }} \\
\text { to } 5^{\text {th }} \text { grade at } 2 \text { schools with no walk to } \\
\text { school programs in school district. } \\
\text { Control group: } 123 \text { students in } 1^{\text {st }} \text { to } \\
5^{\text {th }} \text { grade at } 1 \text { schools with no walk to } \\
\text { school programs in school district. } \\
\text { Age: Intervention: Mean } 8.1 \text { years old } \\
( \pm 1.7) \text {; Control: Mean } 8.4 \text { years old } \\
( \pm 1.6)\end{array}$ & $\begin{array}{l}\text { Name of intervention: Walking School } \\
\text { Bus (WSB) } \\
\text { Duration: } 2 \text { years } \\
\text { Components: Walking school bus lead } \\
\text { by adult WSB leader with designated } \\
\text { walk-stops within } 1 \text { mile radius of the } \\
\text { school. } \\
\text { Control group received no intervention. }\end{array}$ & $\begin{array}{l}\text { Primary outcome: } \\
\text { Prevalence of walking } \\
\text { to/from school; Daily } \\
\text { physical activity levels. } \\
\text { Number of follow-ups: } 6 \\
\text { Follow up time points: } 3 \\
\text { times a year (August, } \\
\text { February, May) over } 2 \text { year } \\
\text { period. }\end{array}$ & $\begin{array}{l}\text { Conflict of } \\
\text { interest: No } \\
\text { Funding source: } \\
\text { American Heart } \\
\text { Association. }\end{array}$ \\
\hline
\end{tabular}




\begin{tabular}{|c|c|c|c|c|c|}
\hline \multirow{2}{*}{$\begin{array}{l}\text { Study author } \\
\text { and year }\end{array}$} & Methods & Participants & Intervention & Outcomes & Notes \\
\hline & & $\begin{array}{l}\text { Gender: } 55.2 \% \text { female, } 44.8 \% \text { male. } \\
\text { Ethnicity: } 90 \% \text { White, } 7 \% \text { Hispanics }\end{array}$ & & & \\
\hline $\begin{array}{l}\text { Hoelscheret } \\
\text { al. (2016) }\end{array}$ & $\begin{array}{l}\text { Design: Quasi- } \\
\text { experimental } \\
\text { Country } \\
\text { (locality): USA }\end{array}$ & $\begin{array}{l}\text { Setting: School based } \\
\text { Intervention group: } \\
\text { Group } 1 \text { (Infrastructure project): } 4^{\text {th }} \\
\text { grade students at } 23 \text { schools with } \\
\text { awarded infrastructure projects. } \\
\text { Group } 2 \text { (Non-infrastructure project): } \\
4^{\text {th }} \text { grade students at } 21 \text { schools with } \\
\text { awarded non-infrastructure projects. } \\
\text { Control group: } 4^{\text {th }} \text { grade students at } 34 \\
\text { matched schools. } \\
\text { Age: } 4^{\text {th }} \text { grade - no specific age range } \\
\text { stated. } \\
\text { Gender: } 48.3 \% \text { female, } 51.7 \% \text { male. } \\
\text { Ethnicity: } \\
\text { Intervention group } 1: 18.8 \% \text { White, } \\
7.1 \% \text { Black or African American, } \\
70.3 \% \text { Latino or Hispanic, } 3.8 \% \text { Other } \\
\text { Intervention group } 2: 25.7 \% \text { White, } 7 \% \\
\text { Black or African American, } 63.6 \% \\
\text { Latino or Hispanic, } 3.7 \% \text { Other } \\
\text { Control: } 25.9 \% \text { White, } 7 \% \text { Black or } \\
\text { African American, } 63.5 \% \text { Latino or } \\
\text { Hispanic, } 3.6 \% \text { Other }\end{array}$ & $\begin{array}{l}\text { Name of intervention: N/A } \\
\text { Duration: Varying } \\
\text { Components: Funding allocation as } \\
\text { intervention: } \\
\text { Infrastructure schools had an SRTS plan } \\
\text { prior to any structural changes - had } \\
\text { several years to complete plan. } \\
\text { Non-infrastructure schools had to submit } \\
\text { an SRTS plan by } 2008 \text { - implementation } \\
\text { was not required. } \\
\text { Control schools were matched but } \\
\text { received no SRTS funding. }\end{array}$ & $\begin{array}{l}\text { Primary outcome: Active } \\
\text { commuting to school counts. } \\
\text { Number of follow-ups: } 4 \\
\text { Follow up time points: } \\
\text { Baseline (2009), interim } 1 \\
\text { (2010), interim } 2 \text { (2011) and } \\
\text { follow-up (2012). }\end{array}$ & $\begin{array}{l}\text { Conflict of } \\
\text { interest: No } \\
\text { Funding source: } \\
\text { Robert Wood } \\
\text { Johnson } \\
\text { Foundation, } \\
\text { Michael \& Susan } \\
\text { Dell Foundation, } \\
\text { The University of } \\
\text { Texas School of } \\
\text { Public Health, } \\
\text { Texas A\&M } \\
\text { Health Science } \\
\text { Center School of } \\
\text { Public Health, } \\
\text { Texas Health } \\
\text { Instituter Live } \\
\text { Smart Texas, and } \\
\text { ther Texas } \\
\text { Department of } \\
\text { Stater Health } \\
\text { Services. }\end{array}$ \\
\hline $\begin{array}{l}\text { McKee et al. } \\
(2007)^{45}\end{array}$ & $\begin{array}{l}\text { Design: Quasi- } \\
\text { experimental } \\
\text { Country } \\
\text { (locality): } \\
\text { Scotland }\end{array}$ & $\begin{array}{l}\text { Setting: School based } \\
\text { Intervention group: } 31 \text { students at } 1 \\
\text { school, living within statutory walking } \\
\text { distance. } \\
\text { Control group: } 29 \text { students at } 1 \\
\text { school, living within statutory walking } \\
\text { distance. } \\
\text { Age: } 9-10 \text { years old - Mean } 9 \text { years old. } \\
\text { Gender: } 60 \% \text { female, } 40 \% \text { male. } \\
\text { Ethnicity: Not stated. }\end{array}$ & $\begin{array}{l}\text { Name of intervention: Travelling Green } \\
\text { Duration: } 10 \text { weeks } \\
\text { Components: Written interactive } \\
\text { resources used by teachers, children and } \\
\text { families - 'curriculum materials', and } \\
\text { 'children and family resources'. Control } \\
\text { group received no intervention. }\end{array}$ & $\begin{array}{l}\text { Primary outcome: Distance } \\
\text { travelled to school by } \\
\text { walking. } \\
\text { Number of follow-ups: } 2 \\
\text { Follow up time points: } \\
\text { Baseline and } 10 \text { weeks. }\end{array}$ & $\begin{array}{l}\text { Conflict } \\
\text { interest: } \mathrm{No} \\
\text { Funding source: } \\
\text { NHS } \quad \text { Greater } \\
\text { Glasgow. }\end{array}$ \\
\hline
\end{tabular}




\begin{tabular}{|c|c|c|c|c|c|}
\hline $\begin{array}{l}\text { Study author } \\
\text { and year }\end{array}$ & Methods & Participants & Intervention & Outcomes & Notes \\
\hline $\begin{array}{l}\text { McMinn et al. } \\
(2012)^{41}\end{array}$ & $\begin{array}{l}\text { Design: Quasi- } \\
\text { experimental } \\
\text { Country } \\
\text { (locality): } \\
\text { Scotland }\end{array}$ & $\begin{array}{l}\text { Setting: School based } \\
\text { Intervention group: } 79 \text { students in P5 } \\
\text { at } 2 \text { schools }-1 \text { school from low } \\
\text { deprivation quartile and } 1 \text { school from } \\
\text { high deprivation quartile. } \\
\text { Control group: } 87 \text { students in P5 at } 3 \\
\text { schools }-1 \text { school from low } \\
\text { deprivation quartile and } 2 \text { school from } \\
\text { high deprivation quartile. } \\
\text { Age: } 8-9 \text { years old. Intervention: Mean } \\
8.7 \text { years old }( \pm 0.51) \text {. Control: Mean } \\
8.6 \text { years old } \pm 0.48) \text {. } \\
\text { Gender: } 40.5 \% \text { female, } 59.5 \% \text { male. } \\
\text { Ethnicity: Not stated. }\end{array}$ & $\begin{array}{l}\text { Name of intervention: Travelling Green } \\
\text { Duration: } 6 \text { weeks } \\
\text { Components: Teacher's handbook with } \\
\text { introductory activities - series of } 13 \\
\text { lessons. Pupil pack describing project } \\
\text { and including activities and handouts. } \\
\text { Control group received no intervention. }\end{array}$ & $\begin{array}{l}\text { Primary outcome: Steps } \\
\text { during total commute; } \\
\text { Moderate-to-vigorous } \\
\text { physical activity (MVPA) } \\
\text { time during total commute. } \\
\text { Number of follow-ups: } 2 \\
\text { Follow up time points: } 5 \\
\text { days pre-intervention and } 5 \\
\text { days post-intervention. }\end{array}$ & $\begin{array}{l}\text { Conflict of } \\
\text { interest: No } \\
\text { Funding source: } \\
\text { National Physical } \\
\text { Activity Research } \\
\text { Evaluation Group } \\
\text { and Sustrans. }\end{array}$ \\
\hline $\begin{array}{l}\text { Mendoza et } \\
\text { al. }(2009)^{49}\end{array}$ & $\begin{array}{l}\text { Design: Quasi- } \\
\text { experimental } \\
\text { Country } \\
\text { (locality): USA }\end{array}$ & $\begin{array}{l}\text { Setting: School based } \\
\text { Intervention group: } 347 \text { students at } 1 \\
\text { school in Seattle (Washington) with no } \\
\text { Parent Teacher Organisation and low } \\
\text { parent involvement at school. } \\
\text { Control group: } 473 \text { students at } 2 \\
\text { schools in Seattle (Washington) with no } \\
\text { Parent Teacher Organisation and low } \\
\text { parent involvement at school. } \\
\text { Age: 5-11 years old. } \\
\text { Gender: Intervention: 44\% female; } \\
\text { Control school 1: 43\% female; Control } \\
\text { school 2: 52\% female. } \\
\text { Ethnicity: } \\
\text { Intervention: 4\% American Indian, } \\
21 \% \text { Asian, 50\% African American, } \\
\text { 20\% Latino, 5\% Caucasian. } \\
\text { Control school 1: 0\% American Indian, } \\
\text { 12\% Asian, 67\% African American, } \\
\text { 18\% Latino, 3\% Caucasian. } \\
\text { Control school 2: 3\% American Indian, } \\
2 \% \text { Asian, 80\% African American, 8\% }\end{array}$ & $\begin{array}{l}\text { Name of intervention: Walking School } \\
\text { Bus } \\
\text { Duration: } 1 \text { year } \\
\text { Components: } \\
\text { Walking school bus } \\
\text { School wide activities } \\
\text { Materials on safety } \\
\text { Allocated WSB coordinator } \\
\text { Control group received no intervention. }\end{array}$ & $\begin{array}{l}\text { Primary outcome: } \\
\text { Proportion of student } \\
\text { walking to school. } \\
\text { Number of follow-ups: } 4 \\
\text { Follow up time points: } \\
\text { Baseline, } 1 \text { month, } 6 \text { months } \\
\text { and } 12 \text { months. }\end{array}$ & $\begin{array}{l}\text { Conflict of } \\
\text { interest: No } \\
\text { Funding source: } \\
\text { Washington State } \\
\text { Department of } \\
\text { Transportation, } \\
\text { Robert Wood } \\
\text { Johnson } \\
\text { Foundation, Feet } \\
\text { First, University } \\
\text { of Washington, } \\
\text { United States } \\
\text { Department of } \\
\text { Agriculture. }\end{array}$ \\
\hline
\end{tabular}




\begin{tabular}{|c|c|c|c|c|c|}
\hline Study author & Methods & Participants & Intervention & Outcomes & Notes \\
\hline & & Latino, $8 \%$ Caucasian. & & & \\
\hline $\begin{array}{l}\text { Mendoza et } \\
\text { al. }(2011)^{50}\end{array}$ & $\begin{array}{l}\text { Design: RCT } \\
\text { Country } \\
\text { (locality): USA }\end{array}$ & 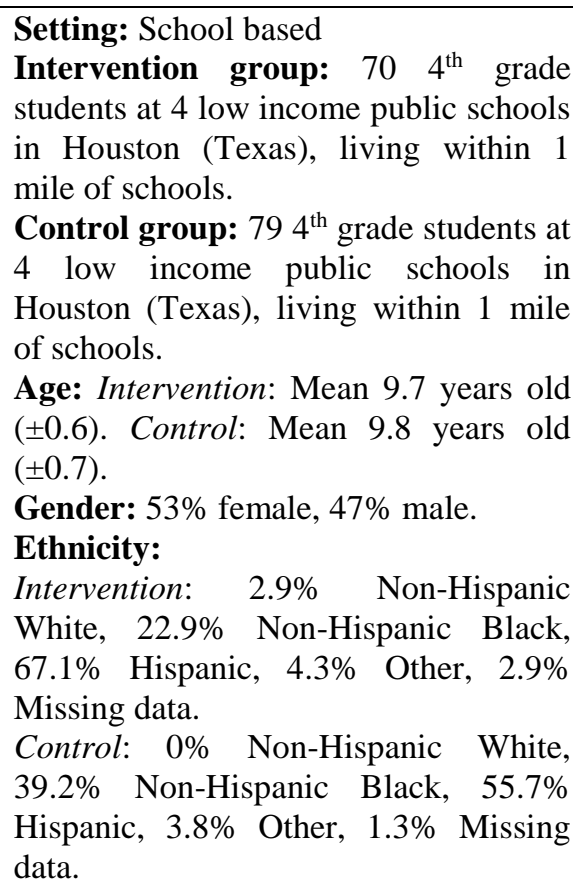 & $\begin{array}{l}\text { Name of intervention: Walking School } \\
\text { Bus } \\
\text { Duration: } 5 \text { weeks } \\
\text { Components: } 3 \text { walking school bus } \\
\text { routes with trained staff leading the walk. } \\
\text { Control group received no intervention. }\end{array}$ & $\begin{array}{l}\text { Primary outcome: } \\
\text { Percentage of trips made by } \\
\text { active commuting over } 1 \\
\text { school week; Daily minutes } \\
\text { of MVPA. } \\
\text { Number of follow-ups: } 2 \\
\text { Follow up time points: } \\
\text { Baseline and during week } 4 \\
\text { and } 5 \text { of intervention. }\end{array}$ & $\begin{array}{l}\text { Conflict of } \\
\text { interest: No } \\
\text { Funding source: } \\
\text { National Institutes } \\
\text { of Health }\end{array}$ \\
\hline
\end{tabular}




\begin{tabular}{|c|c|c|c|c|c|}
\hline $\begin{array}{l}\text { Study author } \\
\text { and year }\end{array}$ & Methods & Participants & Intervention & Outcomes & Notes \\
\hline $\begin{array}{l}\text { Ming Wen et } \\
\text { al. }(2008)^{46}\end{array}$ & $\begin{array}{l}\text { Design: Cluster } \\
\text { RCT } \\
\text { Country } \\
\text { (locality): } \\
\text { Australia }\end{array}$ & $\begin{array}{l}\text { Setting: School based } \\
\text { Intervention group: } 1094 \text { students } \\
\text { from } 12 \text { schools in inner West Sydney. } \\
\text { Average } 92 \text { students per cluster. } \\
\text { Control group: } 1164 \text { students from } 12 \\
\text { schools in inner West Sydney. Average } \\
97 \text { students per cluster. } \\
\text { Age: } 10-11 \text { year olds } \\
\text { Gender: } 52.7 \% \text { female, } 47.3 \% \text { male } \\
\text { Ethnicity: Not stated }\end{array}$ & $\begin{array}{l}\text { Name of intervention: Multi- } \\
\text { component programme. } \\
\text { Duration: } 2 \text { years } \\
\text { Components: } \\
\text { School - student survey, home to school } \\
\text { mapping exercise, preparation for high } \\
\text { school; } \\
\text { Teachers - training, classroom materials, } \\
\text { travel access guide; } \\
\text { Parents - survey, newsletter, meetings; } \\
\text { Council - Review of safety and } \\
\text { walkability near schools and efforts to } \\
\text { improve. }\end{array}$ & $\begin{array}{l}\text { Primary outcome: Mode of } \\
\text { travel to school - student } \\
\text { and parent reported } \\
\text { Number of follow-ups: } 2 \\
\text { Follow up time points: } \\
\text { Baseline and } 2 \text { years }\end{array}$ & $\begin{array}{l}\text { Conflict } \\
\text { interest: No } \\
\text { Funding source: } \\
\text { Central Sydney } \\
\text { Walk to School } \\
\text { Research Program } \\
-\quad \text { NSW } \\
\text { Department of } \\
\text { Health }\end{array}$ \\
\hline $\begin{array}{l}\text { Ostergaard et } \\
\text { al. }(2015)^{55}\end{array}$ & $\begin{array}{l}\text { Design: Quasi- } \\
\text { experimental } \\
\text { Country } \\
\text { (locality): } \\
\text { Denmark }\end{array}$ & $\begin{array}{l}\text { Setting: School based } \\
\text { Intervention group: } 1296 \text { students in } \\
4^{\text {th }} \text { and } 5^{\text {th }} \text { grade at } 13 \text { schools in } \\
\text { Copenhagan, Fredericia and Funen } \\
\text { Control group: } 1105 \text { students in } 4^{\text {th }} \\
\text { and } 5^{\text {th }} \text { grade at } 12 \text { schools in } \\
\text { Copenhagan, Fredericia and Funen } \\
\text { Age: Intervention: Mean } 11 \text { years old } \\
( \pm 0.64) \text {. Control: Mean } 10.9 \text { years old } \\
( \pm 0.63) \text {. } \\
\text { Gender: } 50 \% \text { female, } 50 \% \text { male. } \\
\text { Ethnicity: Not stated. }\end{array}$ & $\begin{array}{l}\text { Name of intervention: N/A } \\
\text { Duration: Varying } \\
\text { Components: Infrastructural changes } \\
\text { near schools. } \\
\text { Hard interventions - structural changes } \\
\text { near the school. } \\
\text { Soft interventions - focused on } \\
\text { increasing motivation and safety. } \\
\text { Control group received no intervention. }\end{array}$ & $\begin{array}{l}\text { Primary outcome: Long } \\
\text { term frequency of cycling to } \\
\text { school; Cycling to/from } \\
\text { school frequency last week. } \\
\text { Number of follow-ups: } 2 \\
\text { Follow up time points: } \\
\text { Baseline and } 1 \text { year. }\end{array}$ & $\begin{array}{l}\text { Conflict of } \\
\text { interest: No } \\
\text { Funding source: } \\
\text { Trygfonden }\end{array}$ \\
\hline $\begin{array}{l}\text { Sirard et al. } \\
(2008) 47\end{array}$ & $\begin{array}{l}\text { Design: RCT } \\
\text { Country } \\
\text { (locality): USA }\end{array}$ & $\begin{array}{l}\text { Setting: School based } \\
\text { Intervention group: } 5 \text { students in } 3^{\text {rd }} \\
\text { to } 5^{\text {th }} \text { grade, at } 1 \text { school, being driven to } \\
\text { school at least } 4 \text { times a week. } \\
\text { Control group: } 6 \text { students in } 3^{\text {rd }} \text { to } 5^{\text {th }} \\
\text { grade being driven to school at least } 4 \\
\text { times a week }- \text { from same school as } \\
\text { intervention students. } \\
\text { Age: Intervention: Mean } 9.5 \text { years old } \\
( \pm 1.02) \text {. Control: Mean } 9.7 \text { years old }\end{array}$ & $\begin{array}{l}\text { Name of intervention: Walking School } \\
\text { Bus } \\
\text { Duration: } 2 \text { weeks } \\
\text { Components: } 1 \text { week of no intervention. } \\
2^{\text {nd }} \text { week consisted of a walking school } \\
\text { bus led by study personnel with use of a } \\
\text { wagon to transport backpacks and } \\
\text { instruments. Control group received no } \\
\text { intervention. }\end{array}$ & $\begin{array}{l}\text { Primary outcome: } \\
\text { Percentage of time in MVPA } \\
\text { during before/after school } \\
\text { commute time. } \\
\text { Number of follow-ups: } 14 \\
\text { Follow up time points: } \\
\text { Daily for } 14 \text { days. }\end{array}$ & $\begin{array}{l}\text { Conflict } \\
\text { interest: No } \\
\text { Funding source: } \\
\text { National Heart, } \\
\text { Lung, and Blood } \\
\text { Institute }\end{array}$ \\
\hline
\end{tabular}




\begin{tabular}{|c|c|c|c|c|c|}
\hline \multirow{2}{*}{$\begin{array}{l}\text { Study author } \\
\text { and year }\end{array}$} & Methods & Participants & Intervention & Outcomes & Notes \\
\hline & & $\begin{array}{l}( \pm 0.90) . \\
\text { Gender: } 45 \% \text { female, } 55 \% \text { male. } \\
\text { Ethnicity: Intervention: } 100 \% \\
\text { Caucasian. Control: } 83 \% \text { Caucasian, } \\
\text { 16\% Chinese. }\end{array}$ & & & \\
\hline $\begin{array}{l}\text { Villa- } \\
\text { Gonzalez et } \\
\text { al. }(2015)^{40}\end{array}$ & $\begin{array}{l}\text { Design: } \\
\text { Controlled trial } \\
\text { Country } \\
\text { (locality): Spain }\end{array}$ & $\begin{array}{l}\text { Setting: School based } \\
\text { Intervention group: } 117 \text { students from } \\
5 \text { schools in Granada and Jaen. } \\
\text { Control group: } 89 \text { students from } 5 \\
\text { schools in Granada and Jaen. } \\
\text { Age: } 8-11 \text { years. } \\
\text { Gender: Not stated. } \\
\text { Ethnicity: Not stated. }\end{array}$ & $\begin{array}{l}\text { Name of intervention: N/A } \\
\text { Duration: } 6 \text { months } \\
\text { Components: Monthly activities of } 60- \\
120 \text { minutes duration during school } \\
\text { hours: } \\
\text { Introductory activities } \\
\text { Story reading related to active travel } \\
\text { Knowledge of environment near school } \\
\text { Road safety } \\
\text { Street behaviour } \\
\text { Traditional games } \\
\text { Control group received no intervention. } \\
\end{array}$ & $\begin{array}{l}\text { Primary outcome: } \\
\text { Percentage of time in MVPA } \\
\text { during before/after school } \\
\text { commute time. } \\
\text { Number of follow-ups: } 3 \\
\text { Follow up time points: } \\
\text { Baseline, post-intervention } \\
\text { and } 6 \text { month follow-up. }\end{array}$ & $\begin{array}{l}\text { Conflict } \\
\text { interest: No } \\
\text { Funding source: } \\
\text { University of } \\
\text { Granada }\end{array}$ \\
\hline $\begin{array}{l}\text { Villa- } \\
\text { Gonzalez et } \\
\text { al. }(2017)^{30}\end{array}$ & $\begin{array}{l}\text { Design: Quasi- } \\
\text { experimental } \\
\text { Country } \\
\text { (locality): Spain }\end{array}$ & $\begin{array}{l}\text { Setting: School based } \\
\text { Intervention group: } 141 \text { students from } \\
5 \text { schools in Granada and Jaen. } \\
\text { Control group: } 110 \text { students from } 5 \\
\text { schools in Granada and Jaen. } \\
\text { Age: } 8-11 \text { years old. Mean } 9.13 \text { years } \\
\text { old. } \\
\text { Gender: Intervention: } 48.3 \% \text { female. } \\
\text { Control: } 50.9 \% \text { female. } \\
\text { Ethnicity: Not stated. }\end{array}$ & $\begin{array}{l}\text { Name of intervention: N/A } \\
\text { Duration: } 6 \text { months } \\
\text { Components: Monthly educational and } \\
\text { encouraging activities of } 60-120 \text { minutes } \\
\text { duration during school hours. } \\
\text { Control group received no intervention. }\end{array}$ & $\begin{array}{l}\text { Primary outcome: Mode of } \\
\text { commuting to school; } \\
\text { Physical fitness. } \\
\text { Number of follow-ups: } 2 \\
\text { Follow up time points: } \\
\text { Baseline and } 6 \text { months. }\end{array}$ & $\begin{array}{l}\text { Conflict of } \\
\text { interest: No } \\
\text { Funding source: } \\
\text { Not funded. }\end{array}$ \\
\hline
\end{tabular}




\section{$\underline{\text { Supplement C }}$}

Methodological quality of each quality assessment component for included studies.

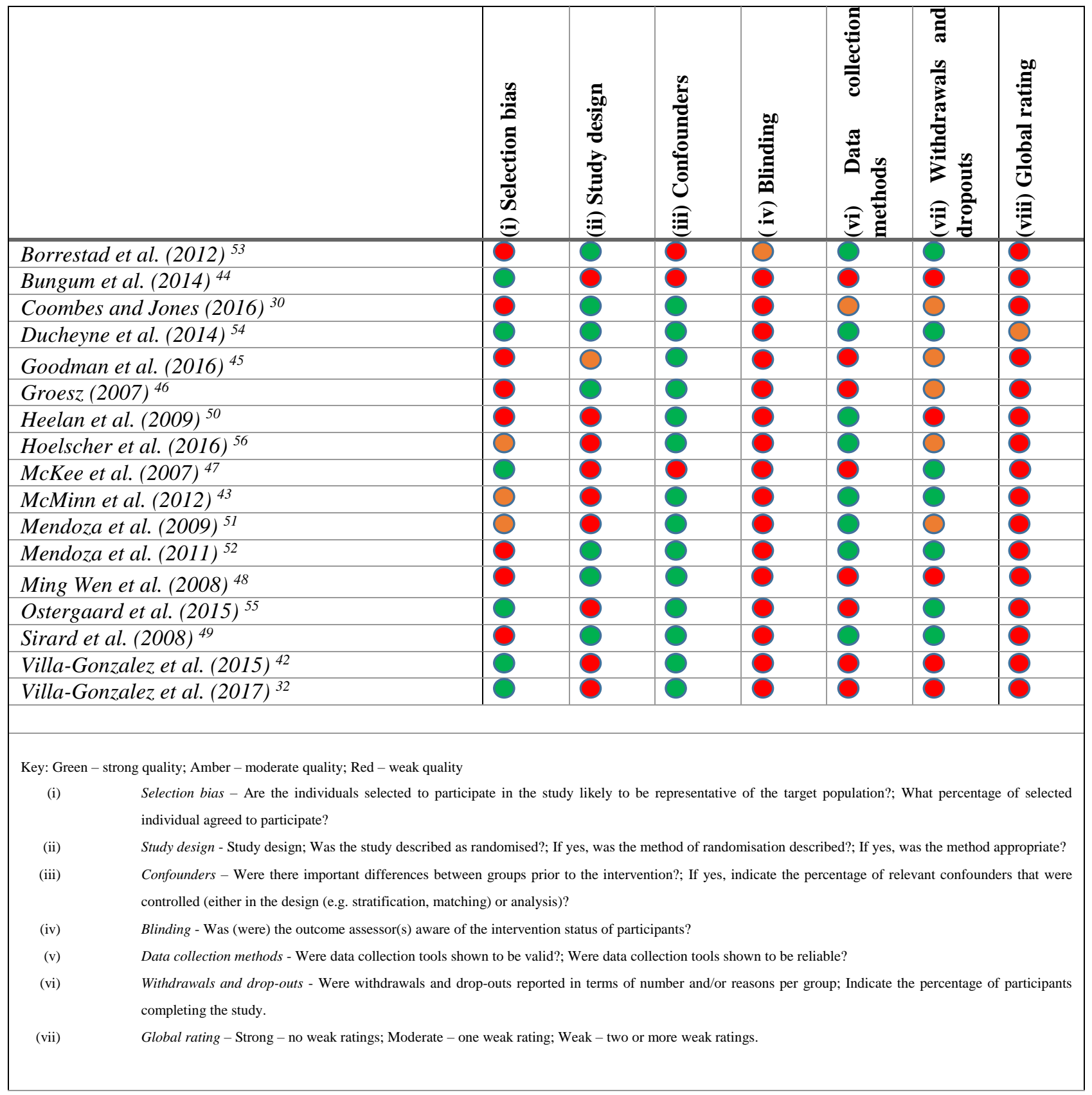




\section{Supplement D: Cohen's d effect size}

The table below details the method of calculating the effect size with the final value for Cohen's $d$ and the interpreted classification.

\begin{tabular}{|c|c|c|c|}
\hline $\begin{array}{c}\text { Study author and } \\
\text { year }\end{array}$ & Outcome measure & Formula & Cohen's d and classification \\
\hline $\begin{array}{l}\text { Borrestad et al. } \\
(2012)^{53}\end{array}$ & $\begin{array}{l}\text { Maximal oxygen } \\
\text { consumption in } \mathrm{VO}^{2} \text { peak. }\end{array}$ & $\begin{array}{l}\mathrm{d}=\mathrm{Xe}-\mathrm{Xc} / \mathrm{SDp} \\
\mathrm{SDp}=\left((\mathrm{Ne} * \mathrm{SDe})+\mathrm{Nc}^{*}\right. \\
\mathrm{SDc})) / \mathrm{SD} \text { total }\end{array}$ & $\begin{array}{l}\mathrm{d}=-0.3038 \\
\text { Class: Negative, small }\end{array}$ \\
\hline $\begin{array}{l}\text { Bungum et al. (2014) } \\
44\end{array}$ & $\begin{array}{l}\text { Number of students } \\
\text { using active travel to } \\
\text { school. }\end{array}$ & $\begin{array}{l}\mathrm{P} \text { one-tailed }=\mathrm{P} \text { two-tailed } \\
\text { / 2. Look up associated } \mathrm{Z} \\
\text { in normal probability table. } \\
\text { (Meta-calculator) }\end{array}$ & $\begin{array}{l}\mathrm{d}=0.0446 \\
\text { Class: Positive, trivial }\end{array}$ \\
\hline $\begin{array}{l}\text { Coombes and Jones } \\
(2016)^{30}\end{array}$ & 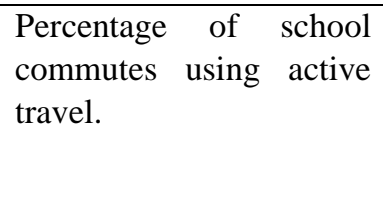 & $\begin{array}{l}\mathrm{P} \text { one-tailed }=\mathrm{P} \text { two-tailed } \\
\text { / } 2 . \text { Look up associated } \mathrm{Z} \\
\text { in normal probability table. } \\
\text { (Meta-calculator) }\end{array}$ & $\begin{array}{l}\mathrm{d}=0.4886 \\
\text { Class: Positive, small }\end{array}$ \\
\hline $\begin{array}{lll}\text { Ducheyne } & \text { et } & \text { al. } \\
(2014)^{54} & & \end{array}$ & $\begin{array}{l}\text { Minutes of cycling to } \\
\text { school a week. }\end{array}$ & $\begin{array}{l}\mathrm{P} \text { one-tailed }=\mathrm{P} \text { two-tailed } \\
\text { / 2. Look up associated } \mathrm{Z} \\
\text { in normal probability table. } \\
\text { (Meta-calculator) }\end{array}$ & $\begin{array}{l}\mathrm{d}=0.0855 \\
\text { Class: Positive, trivial }\end{array}$ \\
\hline $\begin{array}{l}\text { Goodman, van Sluijs } \\
\text { \& Ogilvie }(2016)^{45}\end{array}$ & $\begin{array}{l}\text { Percentage of children } \\
\text { that usually travel to } \\
\text { school by bike. }\end{array}$ & $\begin{array}{l}\text { Accurate calculation not } \\
\text { possible because the } \\
\text { standard deviation was not } \\
\text { provided for either group. } \\
\text { A specific P-value was } \\
\text { also not stated. }\end{array}$ & \\
\hline Groesz $(2007)^{46}$ & $\begin{array}{l}10 \text { day concurrent } \\
\text { bicycling / walking to } \\
\text { school. } \\
\text { Retrospective } 5 \text { day } \\
\text { bicycling / walking to } \\
\text { school. }\end{array}$ & $\begin{array}{l}\mathrm{d}=\mathrm{Xe}-\mathrm{Xc} / \mathrm{SDp} \\
\mathrm{SDp}=\left((\mathrm{Ne} * \mathrm{SDe})+\mathrm{Nc}^{*}\right. \\
\mathrm{SDc})) / \mathrm{SD} \text { total }\end{array}$ & $\begin{array}{l}\text { 10 day concurrent bicycling: } \\
\mathrm{d}=0.1184 \\
\text { Class: Positive, trivial } \\
10 \text { day concurrent walking: } \\
\mathrm{d}=0.1140 \\
\text { Class: Positive, trivial } \\
\text { Retrospective } 5 \text { day bicycling: } \\
\mathrm{d}=-0.1008 \\
\text { Class: Negative, trivial } \\
\text { Retrospective } 5 \text { day walking: } \\
\mathrm{d}=-0.6867 \\
\text { Class: Negative, moderate }\end{array}$ \\
\hline
\end{tabular}




\begin{tabular}{|c|c|c|c|}
\hline Heelan et al. $(2009)^{50}$ & $\begin{array}{l}\text { Minutes of physical } \\
\text { activity a day. }\end{array}$ & $\begin{array}{l}\text { Accurate calculation not } \\
\text { possible because the } \\
\text { sample size was not } \\
\text { provided for either group. } \\
\text { A specific P-value was } \\
\text { also not stated. }\end{array}$ & \\
\hline $\begin{array}{l}\text { Hoelscheret } \quad \text { al. } \\
(2016)^{56}\end{array}$ & $\begin{array}{l}\text { Total number active } \\
\text { commuting to school. }\end{array}$ & $\begin{array}{l}\text { Accurate calculation not } \\
\text { possible because the both } \\
\text { sample size and standard } \\
\text { deviations were not } \\
\text { provided for either group. } \\
\text { A specific P-value was } \\
\text { also not stated. }\end{array}$ & \\
\hline$\underset{47}{\text { McKee et al. (2007) }}$ & $\begin{array}{l}\text { Mean difference in } \\
\text { distance travelled to } \\
\text { school by walking } \\
\text { between baseline and } \\
\text { follow-up. }\end{array}$ & $\begin{array}{l}\mathrm{d}=\mathrm{Xe}-\mathrm{Xc} / \mathrm{SDp} \\
\mathrm{SDp}=\left((\mathrm{Ne} * \mathrm{SDe})+\mathrm{Nc}^{*}\right. \\
\mathrm{SDc})) / \mathrm{SD} \text { total }\end{array}$ & $\begin{array}{l}\mathrm{d}=-0.1312 \\
\text { Class: Negative, very large }\end{array}$ \\
\hline $\begin{array}{l}\text { McMinn et al. (2012) } \\
43\end{array}$ & $\begin{array}{l}\text { Steps during total } \\
\text { commute. } \\
\text { MVPA time during total } \\
\text { commute. }\end{array}$ & & $\begin{array}{l}\text { Steps during total commute: } \\
\mathrm{d}=-0.2906 \\
\text { Class: Positive, trivial } \\
\text { MVPA time during total } \\
\text { commute: } \\
\mathrm{d}=-0.1217 \\
\text { Class: Positive, trivial }\end{array}$ \\
\hline $\begin{array}{lll}\text { Mendoza } & \text { et } & a l . \\
(2009)^{51} & & \end{array}$ & $\begin{array}{l}\text { Number of students } \\
\text { transported to school by } \\
\text { walking. }\end{array}$ & $\begin{array}{l}\mathrm{d}=\mathrm{Xe}-\mathrm{Xc} / \mathrm{SDp} \\
\mathrm{SDp}=((\mathrm{Ne} * \mathrm{SDe})+\mathrm{Nc} * \\
\mathrm{SDc})) / \mathrm{SD} \text { total }\end{array}$ & $\begin{array}{l}\mathrm{d}=12.2347 \\
\text { Class: Positive, very large }\end{array}$ \\
\hline $\begin{array}{lll}\text { Mendoza } & \text { et } & a l . \\
(2011)^{52} & & \end{array}$ & $\begin{array}{l}\text { Weekly percentage of } \\
\text { active commuting. } \\
\text { Daily minutes of MVPA. }\end{array}$ & $\begin{array}{l}\mathrm{d}=\mathrm{Xe}-\mathrm{Xc} / \mathrm{SDp} \\
\mathrm{SDp}=\left((\mathrm{Ne} * \mathrm{SDe})+\mathrm{Nc}^{*}\right. \\
\mathrm{SDc})) / \mathrm{SD} \text { total }\end{array}$ & $\begin{array}{l}\text { Weekly percentage of active } \\
\text { commuting: } \\
\mathrm{d}=2.3670 \\
\text { Class: Positive, very large } \\
\text { Daily minutes of MVPA: } \\
\mathrm{d}=1.7069 \\
\text { Class: Positive, very large }\end{array}$ \\
\hline $\begin{array}{l}\text { Ming Wen et al. } \\
(2008)^{48}\end{array}$ & $\begin{array}{l}\text { Change in percentage of } \\
\text { active travel commutes } \\
\text { to school in usual week } \\
\text { between baseline and } \\
\text { follow-up. }\end{array}$ & $\begin{array}{l}\mathrm{d}=\mathrm{Xe}-\mathrm{Xc} / \mathrm{SDp} \\
\mathrm{SDp}=((\mathrm{Ne} * \mathrm{SDe})+\mathrm{Nc} * \\
\mathrm{SDc})) / \mathrm{SD} \text { total }\end{array}$ & $\begin{array}{l}\mathrm{d}=0.887 \\
\text { Class: Positive, large }\end{array}$ \\
\hline $\begin{array}{l}\text { Ostergaard et } \quad \text { al. } \\
(2015)^{55}\end{array}$ & $\begin{array}{l}\text { Change in long term } \\
\text { school cycling. } \\
\text { Change in school cycling }\end{array}$ & $\begin{array}{l}\mathrm{P} \text { one-tailed = P two-tailed } \\
\text { / } 2 . \text { Look up associated } \mathrm{Z} \\
\text { in normal probability table. }\end{array}$ & $\begin{array}{l}\text { Change in long term school } \\
\text { cycling: }\end{array}$ \\
\hline
\end{tabular}




\begin{tabular}{|c|c|c|c|}
\hline & $\begin{array}{l}\text { trips in the last week. } \\
\text { Change in cardiovascular } \\
\text { fitness. }\end{array}$ & (Meta-calculator) & $\begin{array}{l}\mathrm{d}=-0.036 \\
\text { Class: Negative, trivial } \\
\text { Change in school cycling trips } \\
\text { in the last week: } \\
\mathrm{d}=0.038 \\
\text { Class: Positive, trivial } \\
\text { Change in cardiovascular } \\
\text { fitness: } \\
\mathrm{d}=-0.1773 \\
\text { Class: Negative, large }\end{array}$ \\
\hline Sirard et al. $(2008)^{49}$ & 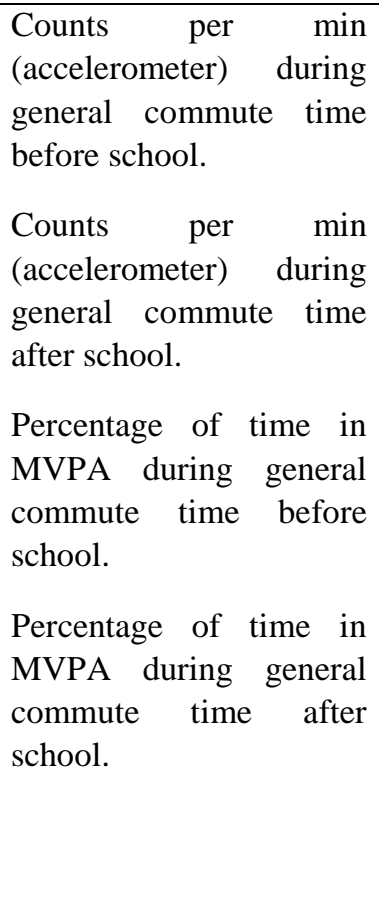 & $\begin{array}{l}\mathrm{d}=\mathrm{Xe}-\mathrm{Xc} / \mathrm{SDp} \\
\mathrm{SDp}=\left((\mathrm{Ne} * \mathrm{SDe})+\mathrm{Nc}^{*}\right. \\
\mathrm{SDc})) / \mathrm{SD} \text { total }\end{array}$ & $\begin{array}{l}\text { Counts per min - before school: } \\
\mathrm{d}=4.1634 \\
\text { Class: Positive, very large } \\
\text { Counts per min - after school: } \\
\mathrm{d}=-0.1247 \\
\text { Class: Negative, trivial } \\
\text { Percent of MVPA time - before } \\
\text { school: } \\
\mathrm{d}=3.7273 \\
\text { Class: Positive, very large } \\
\text { Percent of MVPA time - after } \\
\text { school: } \\
\mathrm{d}=0.1642 \\
\text { Class: Positive, trivial }\end{array}$ \\
\hline $\begin{array}{l}\text { Villa-Gonzalez et al. } \\
(2015)^{42}\end{array}$ & $\begin{array}{l}\text { Number commuting by } \\
\text { walking a week. } \\
\text { Number commuting by } \\
\text { bicycling a week. }\end{array}$ & $\begin{array}{l}\mathrm{d}=\mathrm{Xe}-\mathrm{Xc} / \mathrm{SDp} \\
\mathrm{SDp}=\left((\mathrm{Ne} * \mathrm{SDe})+\mathrm{Nc}^{*}\right. \\
\mathrm{SDc})) / \mathrm{SD} \text { total }\end{array}$ & $\begin{array}{l}\text { Number commuting by walking } \\
\text { a week: } \\
\mathrm{d}=3.2051 \\
\text { Class: Positive, large } \\
\text { Number commuting by bicycling } \\
\text { a week: } \\
\mathrm{d}=-0.1 \\
\text { Class: Negative, trivial }\end{array}$ \\
\hline $\begin{array}{l}\text { Villa-Gonzalez et al. } \\
(2017)^{32}\end{array}$ & $\begin{array}{l}\text { Frequency of active } \\
\text { commuting to school per } \\
\text { week. } \\
\text { Maximal oxygen } \\
\text { consumption }\left(\mathrm{VO}_{\text {max }}^{2}\right) .\end{array}$ & $\begin{array}{l}\mathrm{d}=\mathrm{Xe}-\mathrm{Xc} / \mathrm{SDp} \\
\mathrm{SDp}=\left((\mathrm{Ne} * \mathrm{SDe})+\mathrm{Nc}^{*}\right. \\
\mathrm{SDc})) / \mathrm{SD} \text { total }\end{array}$ & $\begin{array}{l}\text { Frequency of active commuting: } \\
\mathrm{d}=-4.6874 \\
\text { Class: Positive, very large } \\
\text { Maximal oxygen consumption: }\end{array}$ \\
\hline
\end{tabular}




\begin{tabular}{|l|l|l|l|}
\hline & $\begin{array}{l}\text { Data provided is } \\
\text { categorised by gender. }\end{array}$ & $\begin{array}{l}\mathrm{d}=-9.4806 \\
\text { Class: Negative, very large }\end{array}$ \\
\hline
\end{tabular}

